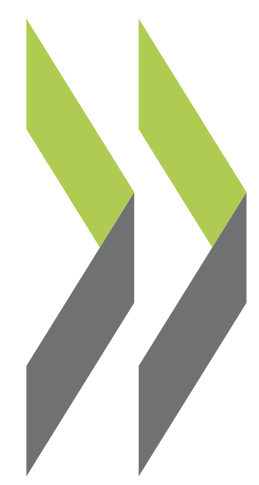

OECD Science, Technology and Industry Working Papers $2002 / 16$

\title{
Using Patents Data to Map Technical Change in Health- Related Areas
}


Organisation de Coopération et de Développement Economiques

Organisation for Economic Co-operation and Development

16-Jan-2003

DIRECTORATE FOR SCIENCE, TECHNOLOGY AND INDUSTRY

English text only

STI WORKING PAPERS 2002/16

USING PATENTS DATA TO MAP TECHNICAL CHANGE IN HEALTH-RELATED AREAS

Frank Lichtenberg and Suchin Virabhak 


\section{STI Working Paper Series}

The Working Paper series of the OECD Directorate for Science, Technology and Industry is designed to make available to a wider readership selected studies prepared by staff in the Directorate or by outside consultants working on OECD projects. The papers included in the series cover a broad range of issues, of both a technical and policy-analytical nature, in the areas of work of the DSTI. The Working Papers are generally available only in their original language - English or French - with a summary in the other.

Comment on the papers is invited, and should be sent to the Directorate for Science, Technology and Industry, OECD, 2 rue André Pascal, 75775 Paris Cedex 16, France.

The opinions expressed in these papers are the sole responsibility of the author(s) and do not necessarily reflect those of the OECD or of the governments of its member countries.

http://www.oecd.org/sti/working-papers

Copyright OECD, 2002

Applications for permission to reproduce or translate all or part of this material should be made to:

OECD Publications, 2 rue André-Pascal, 75775 Paris, Cedex 16, France. 
DSTI/DOC(2002)16

\title{
USING PATENTS DATA TO MAP TECHNICAL CHANGE IN HEALTH-RELATED AREAS
}

\author{
Frank R. Lichtenberg \\ Courtney C. Brown Professor of Business \\ Columbia University, New York, USA \\ and \\ Suchin Virabhak \\ Department of Economics \\ Columbia University
}

\begin{abstract}
This document ${ }^{*}$ reports findings regarding the use of patents data for understanding various dimensions of technical change in health-related areas. Reported counts are based on "Triadic Patent Families", that is sets of patents covering a single invention, filed altogether in Europe, Japan and the US. There were nearly 40000 health-related patent families filed in the 1988-1995 period, which is $16 \%$ of the total number of patent families, with a majority (58\%) of Medical Preparations (mainly drugs), followed by Surgery (13\%), Media Devices (10\%) and Prostheses (9\%). The share of health patent inventors residing in the US is 56\% (it is $35 \%$ in all families), EU is $27 \%$ (32\% in all families), and Japan is $11 \%$ (28\% in all families). The share of the US has been increasing between 1988 and 1995, whereas the share of Japan was shrinking. Internationalisation of research (measured by the share of patents with inventors residing in two or more different countries) has been growing steadily between 1988 and 1995. Research is much more internationalised in drugs than in other health fields. The estimation of an econometric model shows that $R \& D$ has a significant and positive impact on patents, with an $R \& D$ elasticity of 0.43 . Accumulated knowledge, captured by the patent stock variable, is also an important determinant (elasticity of 0.79 ).
\end{abstract}

* A preliminary version of this study was presented at the meeting of the Ad Hoc Group on the OECD Health Project which was held on April 24-26, 2002. 


\title{
USING PATENTS DATA TO MAP TECHNICAL CHANGE IN HEALTH-RELATED AREAS
}

\author{
Frank R. Lichtenberg \\ Courtney C. Brown Professor of Business \\ Columbia University, New York, USA \\ et \\ Suchin Virabhak \\ Department of Economics \\ Columbia University
}

\begin{abstract}
Résumé
Ce document ${ }^{*}$ étudie les enseignements qui peuvent être tirés de l'utilisation des brevets pour comprendre différentes dimensions du progrès technique dans les domaines liés à la santé. Les comptages sont basés sur les "familles triadiques de brevets", qui sont des ensembles de brevets couvrant une même invention, demandés à la fois en Europe, aux États-Unis et au Japon. Il y a eu environ 40000 familles de brevets demandées au cours de la période 1988-1995, soit 16\% du nombre total de familles, avec une majorité (58\%) de Préparations médicales (principalement des médicaments), suivies par la Chirurgie (13\%), les Dispositifs d'introduction (10\%) et les Prothèses $(9 \%)$. La part des inventeurs de brevets liés à la santé résidant aux États-Unis est de 56\% (elle est de 35\% pour l'ensemble des familles), la part de l'UE est de $27 \%$ (32\% pour l'ensemble des familles), et celle du Japon est de 11\% (28\% pour l'ensemble des familles). La part des États-Unis s'est accrue entre 1988 et 1995. L'internationalisation de la recherche (mesurée par la part des brevets ayant des inventeurs résidant dans 2 pays différents ou plus) a progressé entre 1988 et 1995. La recherche est plus internationalisée dans les médicaments que dans les autres champs techniques. L'estimation d'un modèle économétrique montre que la R-D a un effet positif et significatif sur les brevets, avec une élasticité de 0,43. Le stock de connaissance accumulée, mesuré par le stock de brevets, est également un déterminant important (avec une élasticité de 0,79).
\end{abstract}

* Une version préliminaire de cette étude a été présentée lors de la réunion du Groupe ad hoc chargé du projet OCDE sur la santé qui s'est tenue les 24-26 avril 2002. 


\section{TABLE OF CONTENTS}

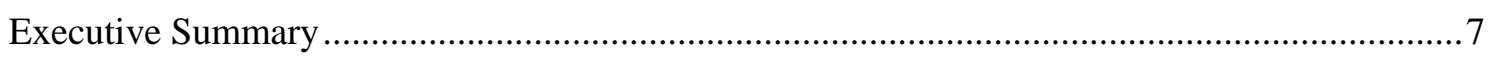

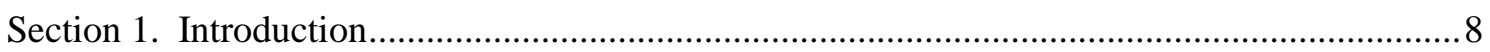

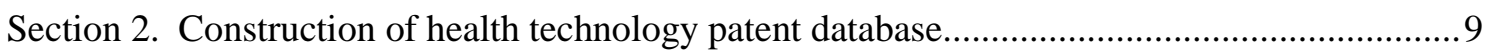

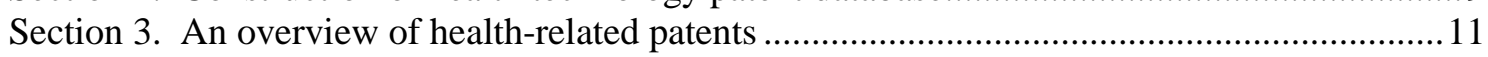

Section 4. Absolute and comparative advantages in health patents............................................ 12

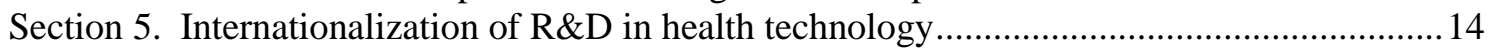

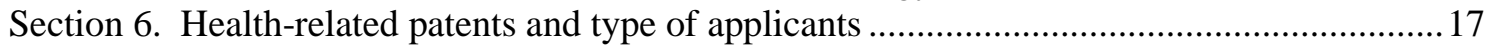

Section 7. A comparison between OECD and US FDA drug data ...........................................19

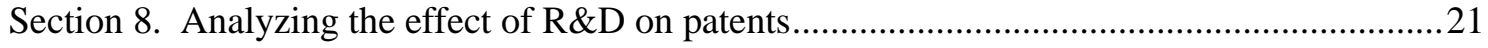

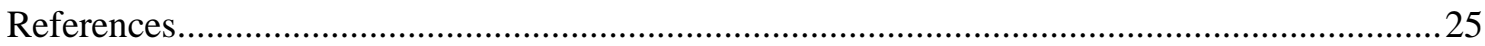

\section{Appendices}

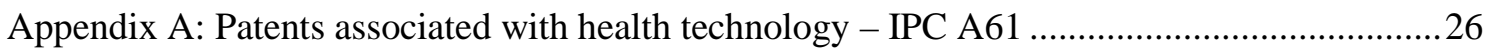

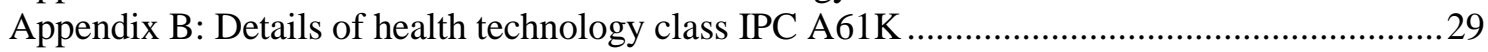

Appendix C: Consolidating health patent applicant names ........................................................ 31

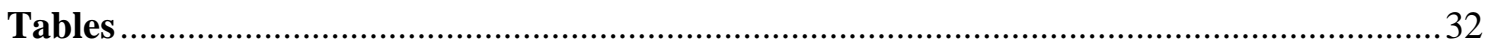

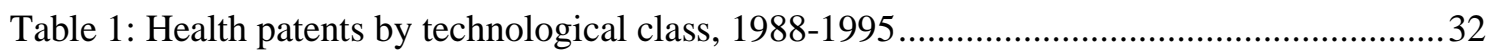

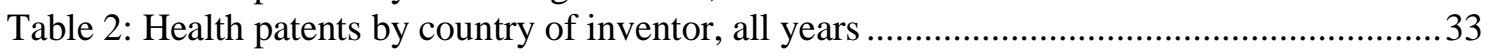

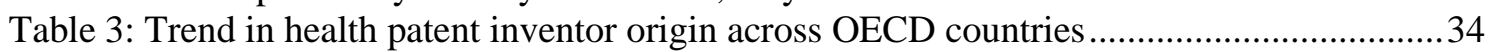

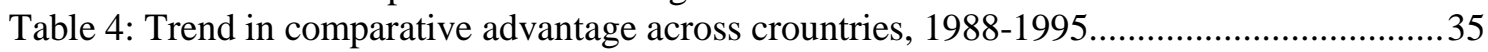

Table 5: Distribution of international co-operation by health technology type .............................37

Table 6: Trend in international co-operation in selected health technologies ...............................37

Table 7: Trend in international co-operation in health technology R\&D ..................................... 38

Table 8: Shared inventions and the number of patents, OECD countries......................................39

Table 9: Role of international co-operation in non-OECD countries ..........................................39

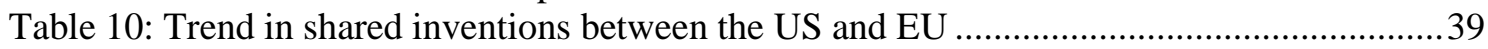

Table 11: Trend in shared inventions between the US and Japan...............................................

Table 12: Distribution of applications by technology, selected countries ....................................40

Table 13: Comparing year-of-grant drug data from the OECD and USPTO .............................41

Table 14: Patent grant date and FDA approval for selected drugs ............................................ 41

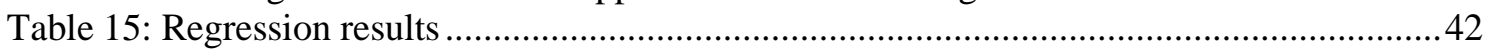


Figures

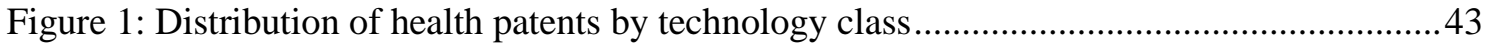

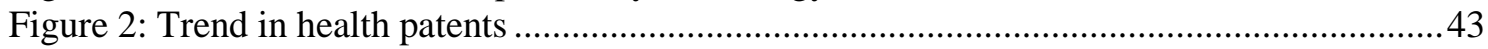

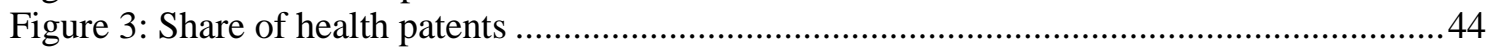

Figure 4: Evolution of selected health patent technologies ....................................................4

Figure 5: Changes in absolute advantages for selected technology classes and countries ............45

Figure 6: Evolution of shared inventions in Medical Preparations in the US.............................45

Figure 7: Distribution of applicants across selected health technologies ..................................46

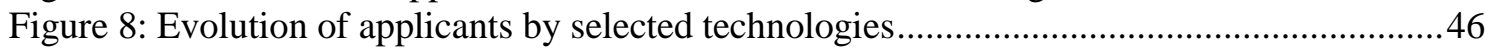

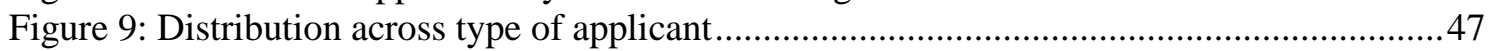

Figure 10a: Type of applicant by technology group - Medical Preparations ................................47

Figure 10b: Type of applicant by technology group - Surgery .................................................... 48

Figure 10c: Type of applicant by technology group - Prostheses etc. …….................................48

Figure 10d: Type of applicant by technology group - Media Devices etc..................................48 
DSTI/DOC(2002)16

\section{EXECUTIVE SUMMARY}

This document reports findings regarding the use of patents data for understanding various dimensions of technical change in health-related areas.

The basic statistical concepts are as follows. Reported counts are based on "Triadic Patent Families". A Triadic Patent Family is defined as a set of patents covering a single invention, filed altogether in Europe, Japan and the US. Relative to other types of patents, patent families have the advantages for statistics of greater international comparability and of capturing the most valuable inventions only. The reported year is the "priority year", which is the year of first filing world-wide. It is recognised as being in general the year of the invention (which is three to six years before the patent is granted).

There were nearly 40000 health-related patent families filed in the $1988-1995$ period, which is $16 \%$ of the total number of patent families. Medical Preparations (mainly drugs) represent $58 \%$ of these patents, followed by Surgery (13\%), Media Devices (10\%) and Prostheses (9\%). The share of health patent inventors residing in the US is $56 \%$ (it is $35 \%$ in all families), EU is $27 \%$ (32\% in all families), and Japan is $11 \%$ ( $28 \%$ in all families). Hence the US has clearly a comparative advantage in health-related technology, as its dominance is stronger than in other areas, whereas Japan is much weaker in this technology field than in others. In addition, the share of the US has been increasing between 1988 and 1995, whereas the share of Japan was shrinking. Non-OECD countries (notably Israel, India and Russia) filed $1.6 \%$ of health-related patent families over the period, which is more than there overall share of $0.9 \%$ in patent families.

Internationalisation of inventions is measured by the share of patents with inventors residing in two or more different countries. This share has been growing steadily between 1988 and 1995, reflecting increasing internationalisation of research in health-related technology (it is the case also in other technology fields). Research is much more internationalised in drugs than in other health fields, which might reflect differing patterns in the organisation of research and international circulation of technology across the various health fields. In health-related areas (as in other areas), US and Japanese research is less internationalised than research from other countries, whereas Switzerland, the UK and Canada are highly internationalised. European countries tend to co-operate with each other, whereas the US co-operates more with Japan and with non-OECD countries (especially Israel).

Companies represent $75 \%$ of the applicants (which is, in general, the entity conducting research), whereas universities are $6 \%$, research agencies are $2 \%$ and hospitals are $1 \%$. As it would be expected, the share of universities is higher (8\%) in drugs, and the share of hospitals is higher (2\%) in Surgery. A more elaborate classification of institutions (distinguishing especially private and public entities) would allow further interpretation of the data.

Using patent data as well as data on R\&D expenditure, we construct an empirical model that describes the impact of business enterprise pharmaceutical $R \& D$ expenditure on patent acquisition across OECD countries. Our empirical results confirm a widely held belief that $R \& D$ has a significant and positive impact on patents. In particular, we obtain an R\&D elasticity of 0.43 . Further, our model supports the claim that accumulated knowledge, captured by the patent stock variable, is also an important determinant (elasticity of 0.79 ). 


\section{SECTION 1. INTRODUCTION}

In this report, data from the OECD "Triadic Patent Families" dataset is analyzed, in particular, health patent technologies across countries through time. The goal of the study is to uncover the distribution and trend in health patents, and to draw inferences about the absolute and comparative advantages across countries in various health technology fields; the role of international co-operation in health technology and so on.

The next section provides an overview of the dataset, as well as a description of how a database on health patent technologies is constructed from it. There is also a brief explanation of the interpretation of certain variables, which will be used to infer trends in absolute and comparative advantages and international co-operation. Last, there is a note of caution about the extent to which patent data alone can reliably reflect technical change in the health care industry. The next four sections delve into the analyses of the health patent data, and flesh out international trends in regard to patent technology fields, residence of inventors, residence of applicants, etc. The penultimate section focuses on drug patents in the US. By comparing data from the OECD and the Food and Drug Administration (FDA), we draw conclusions about the adequacy of the OECD data and implications that any discrepancy may entail. Section 8 analyzes the effect of medical technological progress on longevity and other health outcomes. Last, Section 9 concludes the report with an empirical examination of the impact of R\&D expenditure on patents in the pharmaceutical industry. 
DSTI/DOC(2002)16

\section{SECTION 2. CONSTRUCTION OF HEALTH-RELATED PATENTS DATABASE}

\section{The Triadic Patent Families dataset}

Patent data is obtained from the OECD "Triadic Patent Families" database, which consolidates raw patent data from the EPO (and the WIPO DOCDB database it maintains), JPO and the USPTO. The original OECD dataset groups all patents corresponding to a unique invention into a single row, referred to as a "patent family". As such, each patent family often comprises of more than one International Patent Classification (IPC) code. In order to extract all relevant information on health patents, all relevant patents belonging to IPC code A61 ("Medical or Veterinary Science; Hygiene"), ${ }^{1}$ are identified from "Triadic Patent Families - core data.txt". Next, we decompose then reclassify the data according to eleven main IPC categories, namely A61B, A61C, A61F, A61G, A61H, A61J, A61K, A61L, A61M, A61N, and A61P. We refer to each category as a unique field of health-related patents.

The "core data" also provides information about patent inventor by origin of residence. Should a patent be co-invented by researchers from more than one country, a fractional patent count is employed. This information is used to determine the distribution of health patent by inventor origin across health technology fields. By incorporating the year in which each patent was first granted priority, we can examine the trend in this distribution. This resulting distribution is indicative of the absolute advantage of countries across health technology fields, while its trend reveals to us the dynamics of absolute advantages through the years. Further, if we compare a country's share of health patents to total patents, conclusions regarding comparative advantage may be drawn. Next, we interpret co-invention across countries as illustrating the importance of international co-operation in health care technology. The share of patents that are co-invented shows its relative significance. In addition, we focus on these patents to extract details regarding national trends in international co-operation.

Data on the origin of patent applicants is similar to those on patent inventors insofar as shares are computed for patents with applicants from more than one country of residence. This information is combined with a dataset that lists applicant names. The list of applicants is consolidated into six categories, namely, university, public (government agency), private company, research, educational or medical institutions. ${ }^{2}$ Using these broad classes, we are able to examine the characteristics of patent technology according to the status of applicants. This can be further broken down into status by country and across years.

\section{Interpreting patent data}

From the discussion above, it is evident that a lot can be inferred about the distribution and trend of health technology from patent data alone. However, like all types of data, caution must be exercised when making inferences. First, the dataset provided by the OECD includes only health patents that are patented in all

\footnotetext{
1. See Appendix A and B for details.

2. See Appendix $\mathrm{C}$ for details.
} 
three offices. ${ }^{3}$ In other words, an invention that is protected by patents in the US alone, or in the US and Japan, but not in Europe would be excluded from the Triadic Patent Families database. This is done for the purpose of treating all patentees in the same way, be they from Europe, Japan or the US ("Triadic" patents are not subject to any "home advantage" as they are international in scope). An attempt is made to uncover the degree of discrepancy between the OECD dataset and a country's specific patent distribution by considering drug patent data in the US. From the OECD dataset, we extract patents corresponding to drug patents, namely those in USPC 424 and 514 classes. We then compare this reduced list to that of the US. Food and Drug Administration (FDA), to see how the difference in scope impacts the data. Second, we deduced the significance of international co-operation using data on co-inventor shares. In the dataset, the country of an inventor corresponds to the inventor's country of residence. Should inventors from different countries collaborating on a project choose to reside in one particular country for that period, this may not show up in the statistics as an "international" effort.

Health patents are only the first step to health care. Applicants choose to patent an invention in order to protect it within a jurisdiction. To the extent that a patent is not practically applied to the health care industry, its existence would not affect the technical advancement of health care in that country. One could speculate that the emerging role of intellectual property rights in the recent past has resulted in a surge in patent application. However, if the rate at which patents materialize in the marketplace has remained constant, then the focus on health patent data alone would lead one to over-estimate technical change in the health care industry. Additionally, one could further argue that even if a certain health technology is available in the market, its true impact can only be fully realized if there exists adequate dissemination as well as infrastructure in the health care industry (such as trained personnel). This is particularly poignant if cross-country comparisons are to be drawn. Technical change in health care would be larger in a country with the infrastructure to fully exploit a new health patent available in the market.

3. Although this limits the number of patents included in our dataset and may affect the conclusions drawn, one way to reconcile the use of patents applied to all three patent offices is that we focus on patents that are significant in the international arena. 
DSTI/DOC(2002)16

\section{SECTION 3. AN OVERVIEW OF HEALTH-RELATED PATENTS}

By way of becoming familiar with the data on health-related patents, this section begins by looking at the broad trends in health patents. All analyses in this report are restricted to the period 1988-1995. ${ }^{4}$ Table 1 gives a breakdown of the number of patents by technology class. There are a total of over 40000 health patents in the OECD Triadic Patent Families dataset for the 1988-1995 period. Figure 1 shows a pictorial breakdown of health patents by technology class. Medical Preparations make up the bulk of these patents, constituting $58 \%$ of all health patents. This is followed by Surgery (13\%), Media Devices (10\%), and Prostheses etc. (9\%). The dominance of Medical Preparations is not surprising as this category includes various forms of medicinal preparation (refer to Appendix $\mathrm{C}$ for the complete list of subcategories within this class).

Figure 2 shows the trend in health patents through time, where the year refers to the first priority year of each patent. ${ }^{5}$ The number of health patents actually fell between 1988-1989 and 1989-1990, by $-0.4 \%$ and $-7.2 \%$, respectively. This is followed by a distinct upward trend in the number of health patents between 1990 and 1993, with growth rates in 1990-1991 and 1992-1993 of approximately 15\%. After 1993, the number of health patents fell again, by an average annual rate of $10 \%$. From Figure 3, we see that throughout the period 1988-1995, the share of health patents hovered between $15 \%-20 \%$ of the total number of patents. By comparing Figures 2 and 3, we notice that health patents and its share in total patents both exhibit very similar trends. Figure 4 examines this trend for our four main health patent technologies. As expected, there is a significant increase in the total number of patents throughout the period of analysis. When we focus instead on the rate of change in the average annual number of patents, however, this statistic increased most significantly for Prostheses etc. between 1990-1992 and 1992-1995, while Media Devices maintained an almost steady average annual rate of increase of around 20\% throughout the three sub-periods. The average annual number of patents actually fell for Medical Preparations between 1988-1989 and 1990-1992 from 2999 to 2 906, but increased again to 2954 in the latter period of 1993-1995.

4. Prior to 1988, the EPO was still a new body; after 1995, data for the US may be missing due to delays in the process of granting patents in the US. Hence data for the period 1988-1995 is deemed most complete and would render reliable analyses. It is reminded that the years referred to are priority years, that is, years of first filing for a patent world-wide. The priority date is the closest to the date of invention, hence the most relevant for economic analysis.

5. This is deemed preferable as the filing dates may vary across patent offices. 


\section{SECTION 4. ABSOLUTE AND COMPARATIVE ADVANTAGES IN HEALTH PATENTS}

Table 2 shows the distribution of inventors ${ }^{6}$ of health patents across OECD member countries ranked in descending order. $98.42 \%$ of the inventors of health-related patents reside in OECD member countries. The US accounts for more than half (55.75\%) of the inventors of health patents, a clear indication of its absolute advantage in health technology. It is interesting to note that group of countries that constitute the EU do not, as a whole, outnumber the US in the number of inventors, accounting for only $27 \%$ of health patents collectively. Looking at countries individually, Japan comes a distant second to the US, with over $10 \%$ of the inventors. Germany (7.54\%), France (5.72\%) and the UK (5.54\%) follow closely behind.

Table 3 breaks down the analysis into three distinct periods - 1988-1989, 1990-1992 and 1993-1995. It shows that the US has been the top contributor to new health technology over the years. The ranking of the three most important contributors of inventors, namely the US, Japan and Germany have remained unchanged over the entire period. While the ranking within the top-ten countries have shown some variation, it is noteworthy that the list of countries featured in this top ten list has remained stable over time. The last column of Table 3 shows the change in a country's ranking between 1988-1989 and 1993-1995. A negative value indicates an improvement in a country's ranking. It appears that Korea and New Zealand have made the most dramatic improvement in ranking, moving from rank 19 to 15 and 25 to 19 respectively, between the two periods. This suggests that Korea and New Zealand have gained relative advantage in health technology. On the other extreme, both Norway and the Czech Republic have slipped further behind the ranks over the years. Although the Czech Republic has never been an important contributor to health technology inventors, the same cannot be said of Norway. In 1988-1989, Norway ranked 15th, but by 1993-1995 its position fell to 19 out of 27 .

Figure 5 expands on the concept of absolute advantage, by examining its trend for the four main health technology fields, across major inventor-countries. Note that inventor shares are computed as a percentage of the group's total, for each technology class. The first obvious trend is that the US appears to have enhanced its absolute advantage over the period, across all health technology fields examined. By 1993-1995, more than 70\% of inventors of these top four health fields resided in the US. Japan, on the other hand, appears to have lost its absolute advantage over the years. Its most significant decline are in Medical Preparations and Media Devices, where the percentage of inventors fell by more than $40 \%$ over the period. In the class of Medical Preparations, Germany also registered a significant decline of about $42 \%$. Over the same period however, the US experienced a $30 \%$ increase in the proportion of inventors in this patent field.

Turning our attention to the notion of comparative advantage, Table 4 lists the share of health patents as well as the share of all patents for each country and year, as a percentage of respective world totals. The share of health patent inventors residing in the US is $56 \%$ (it is $35 \%$ in all families), EU is $27 \%$ (32\% in all families), and Japan is $11 \%$ ( $28 \%$ in all families), for the period 1988-1995. Hence the US has clearly a comparative advantage in health-related technology, as its dominance is stronger than in other areas, whereas Japan is much weaker in this technology field than in others. In addition, the share of health patent inventors in the US has been increasing between 1988 and 1995 from 50\% to 62\% respectively, whereas

6. The country of residence of inventors are weighted by a fractional patent count method. 
the share of Japan has been shrinking (14\% in 1988 to $8 \%$ in 1995). Non-OECD (notably Israel, India and Russia) countries filed $1.6 \%$ of health-related patent families over the period, which is more than there overall share of $0.9 \%$ in patent families. In the next section, we attempt to unfold another salient feature of health technology research, namely, the role of international co-operation in the area of health technology R\&D. 


\section{SECTION 5. INTERNATIONALIZATION OF R\&D IN HEALTH TECHNOLOGY}

In order to measure the extent of international co-operation in health technology a proxy of patents were made where the inventors reside in more than one country. ${ }^{7}$ The reduced sample has more than 3500 unique patent entries. Table 5 shows the broad distribution of shared inventions in each health technology field. It is evident that the four main patent fields, namely, Medical Preparations, Prostheses etc., Surgery, and Media Devices, are those in which international co-operation is most intense. Not surprisingly, most shared inventions are in Medical Preparations, with Prostheses etc. and Surgery as distant second and third. The last two columns of Table 5 show the rank in terms of the number of patents with shared inventors, rank (inv), and the rank in terms of total number of patents, rank (number). It can be seen that that, with the exception of Prostheses etc., there is hardly a difference in the ranking positions across all health technology fields. In other words, the degree of international co-operation is directly related to the number of patents in each field. As for Prostheses etc., our preliminary conclusion is that relative to the number of patents, there is proportionally more international co-operation in invention.

More interestingly, Table 6 illustrates how international co-operation has evolved over the years, for the four major health technology fields. It is immediately apparent that there is a trend towards international co-operation in health care technology over the greater period. Except for Prostheses etc., there has been an increase in the number of inventions involving international co-operation. However, growth rates slowed during the latter period, and in fact was negative for Prostheses etc. As for Surgery, there is a steep rise in the growth in the number of international co-operative efforts. Although the rate of growth in the number of shared inventions in Medical Preparations decreased during the last period, its absolute values remained high throughout: 987 and 1007 in 1990-1992 and 1993-1995 respectively. The last column of Table 6 shows the ratio of shared inventions to total patents for each field. The fact that internationalisation is most intensive in drugs (about 11\% of all drug patents during the period 1990-1995) may reflect the difference in patterns of organization of research and international circulation of technology across health fields. Notice too, that for Medical Preparations and Surgery, there has been an upward trend in the intensity of internationalisation.

Table 7 takes a closer look at the trend in international co-operation across all countries. Here, we examine the ratio of the number of shared inventions to the total number of inventions in each country. In the majority of countries, there has been a decline in the change in the proportion of shared inventions, as shown by the last two columns of the table. Less than a third of the countries ( 15 exactly) show an increase in rate of international co-operation. As expected, OECD countries with a large proportion of inventors also register a large number of shared inventors. A more revealing picture is given in Table 8, which compares the proportion of patents to the total number of patents, and the proportion of shared inventions to the total number of shared inventions. It becomes clear that both the US and Japan are relatively less involved in international collaborations. While the US contributes more than half of the total number of patents worldwide, it accounts for only $32 \%$ of shared inventions in the world. Similarly, Japan has a wide discrepancy between the two, of $10.7 \%$ and $5.5 \%$ respectively. On the other hand, the reverse trend for most of the other countries is observed. At the country level, Canada, Switzerland and UK stand out as

7. In our dataset, we note these as entries in which the variable denoting the share of inventor by country is less than one. 
being the relatively more involved in internationalization, with $1.7 \%, 1.9 \%$ and $5.5 \%$ of total patents, but $3.6 \%, 5.9 \%$ and $10.9 \%$ of shared inventions respectively. The EU accounts for $26.9 \%$ of the patents and $27.1 \%$ of the shared inventions (excluding inventions shared by two or more member countries of the EU).

The final observation in the preceding paragraph leads one to examine Table 7 more carefully. While nonOECD countries contribute to an insignificant share of the total number of health patents $(1.6 \%)$, their presence is certainly more noticed in international efforts in health care R\&D (5.9\% of worldwide shared inventions). In fact, non-OECD's proportion of shared inventions makes up about $45 \%$ of its total inventions during 1990-1995. The corresponding percentage for OECD countries is about 17\%. Among the OECD countries, Czech Republic, Ireland, Luxembourg, Mexico, Norway, Poland and Turkey are relatively more dependent on shared inventions; while Israel and Russian Federation stand out amongst non-OECD nations with their lower than average proportion of shared inventions. Table 9 explores the nature of health technology collaborations in ten non-OECD countries, with the aim to uncover the relationship between OECD and non-OECD countries in such joint collaborations. Note that for all non-OECD countries except Israel and the Russian Federation, all international co-operation in health care involved an OECD partner. In addition, the US and EU have both played significant roles in these joint collaborations. This suggests the international diffusion of knowledge between more technologically advanced countries and less advanced ones. With the exception of Brazil, Israel and Monaco, co-operative health care technology development in non-OECD countries that involve both the US and the EU is not a common occurrence.

Israel has the largest number of joint collaborations with other countries, at 179 . This is followed by India, the Russian Federation and China, with (unweighted) shared inventions of 36, 34 and 33 respectively. By comparing the weighted and unweighted number of shared inventions, we may interpret that on average, Israel's inventors had a share of $36 \%$ per patent in international health technology co-operation, (last column of Table 9). Viewed in this light, the Russian Federation has the greatest percentage share per patent of 51\%, followed by South Africa (44\%) and Argentina (40\%). Given that collaborations with the US and the EU constitute a vast majority of these shared inventions, it can be inferred from these figures that both the US and EU are often primary inventors in these co-operative efforts.

Table 8 has shown that compared to its share in total patents, the US participates proportionally less in shared inventions. Still, its primary role in shared inventions justifies a closer investigation of these trends. From Table 9 it can be inferred that the US probably accounts for more than a 50\% stake in shared inventors with non-OECD countries. Tables 10 and 11 present the results of health care R\&D co-operation in health care between the US, and the EU and Japan in turn. In general, collaborations with the EU and Japan are greatest in Medical Preparations, Prostheses etc., Surgery, and Media Devices. Relative to the total number of shared inventions, the US and EU have not co-operated significantly. ${ }^{8}$ In addition, co-operation between the two on average accounts for $60 \%$ of the weighted share per patent. In other words, US-EU efforts are synonymous with collaborations that include third countries. A final observation is that US-EU co-operation in health care appears to be a fairly new phenomenon: apart from Medical Preparations, most collaboration in the other two health technology fields began in the 1990s. In contrast, Table 11 shows that Japan and the US have been co-operating since the late 1980s. Between them, there have been 330 such collaborations. In addition, many of these efforts have been exclusively between the two countries (see final column in Table 11). Another interesting observation is that the US and Japan on average play equally important roles in these collaborations. The two exceptions are the technology field Sterilization, where the US seems to dominate; and Prostheses etc., where there seems to be increasing US dominance. Figure 6 focuses on Medical Preparations. While shared inventions between the US and Japan has shown a steady increase between 1988 and 1995, the rate of change in shared inventions between the US and EU seems to have remained at a low level.

8. It appears then that EU member countries often collaborate between themselves. 
The above statistics all point to the importance of international co-operation in health care, especially between more developed OECD member countries and non-OECD countries; and between EU countries. While the US and Japan have a relatively robust history in health technology co-operation, the same trend is not apparent between the US and EU. 
DSTI/DOC(2002)16

\section{SECTION 6. HEALTH-RELATED PATENTS AND TYPE OF APPLICANTS}

The Triadic Patent Families database includes information about applicants from each patent family. Similar to data about inventor resident country, there is a statistic that describes the share of a patent family attributed to a country of residence of the applicant(s). In a separate file, the names of applicants corresponding to each patent family are available.

Data is broken down according to health technology classes, year and applicant origin and then combined with a database that contains applicant names. Since each entry of the latter dataset corresponds to just one applicant, multiple entries exist for some patents. Of the 40367 patents in total, about $10 \%$ have more than one applicant. Figure 7 gives an overview of the number of applicants ${ }^{9}$ by selected health technology fields. As expected, the distribution of applicants across technology fields is similar to that across number of patents. In other words, Medical Preparations ranks highest, accounting for 59\% of applicants, followed by Surgery (13\%), Media Devices and Prostheses etc. (about 9\% each). In fact, the percentage of applicants in these four technology fields is very closely matched with their respective share of the number of patents. ${ }^{10}$ Next, applicants by country of residence are examined. Table 12 lists countries from which more than $1 \%$ of total applicants resided. All ten countries are OECD members. On average, $27 \%$ and $11 \%$ of health patent applicants are from the US and EU respectively. It is interesting to compare the statistics in Table 12 to that of Table 2 . It reveals is a very strong relationship between the proportion of applicants and inventors between countries.

Figure 8 examines the evolution of applicants over time, for the four most significant health technologies. In general, the (weighted) number of applicants exceeds the number of patents, implying that there is often more than one applicant per patent. For Medical Preparations, there has been an upward trend in the number of applicants per patent over the period 1988-1995. On the other hand, Surgery, Prostheses etc. and Media Devices all register decreases between 1988-1989 and 1990-1995, with the ratio holding almost constant between the periods 1990-1992 and 1993-1995.

Using the dataset with applicant names, information is extracted that may indicate the institutional nature of applicant. The idea behind this is to determine the role of private businesses, the government, educational medical and institutions in health-related patents. ${ }^{11}$

As mentioned at the outset of this section, there may be more than one applicant per patent. Figure 9 graphs the distribution of patents across our six main applicant-type categories. As anticipated, private companies account for the vast majority of applicants, making up about $75.4 \%$ of applicants. University and other educational institutions account for about $5.8 \%$ of patent applications, while medical centers and research agencies make up about $1.2 \%$ and $2.2 \%$ respectively.

9. Note that a fractional count method is applied - hence if there are 2 applicants, then each would be given a count of 0.5 .

10. Compare Figure 1 to Figure 7.

11. As this was a very involved procedure and by no means exhaustive, we explain the details in Appendix C. 
Finally, Figure 10(a-d) is a series of pie-charts that show the distribution between the type of applicant for each of the four main health technology fields. In general, the order of importance is as follows: Company, Other, University, Research, Medical and Public. The only notable exception is with Surgery, where Medical ranks above Research. ${ }^{12}$ While private firms make up more than $70 \%$ of the applicants in all groups, its presence is greatest in Prostheses etc. and Medical Preparations, at $77 \%$ and $76 \%$ respectively. It is also in Medical Preparations that University has a relatively large part to play, amounting to $8 \%$, as compared to around $2.4-4 \%$ in the other three technology classes. This is not surprising as this category includes drugs, for which the private sector contribution has been acknowledged to be immense. ${ }^{13}$ In Surgery, medical institutions play a relatively significant role. It takes up $2.3 \%$ of applicants, unlike other instances where it accounts for around $1 \%$ of applicants.

12. For media devices, the shares of university and research are about equal.

13. Note that most of the educational institutions in the University category are private ones. 
DSTI/DOC(2002)16

\section{SECTION 7. A COMPARISON BETWEEN OECD AND US FDA DRUG DATA}

In Section 1, it was mentioned that the OECD Triadic Patent Families database includes only patents that have been simultaneously applied at the Japan, EU and US patent offices. In order to evaluate the loss of information from the possible exclusion of patents applied to any subset of offices, attention is paid to comparing patent data from other sources. In particular, the focus is on drug-related patent data. In order to ensure consistency, analysis is standardized to patents belonging to USPC groups 424 and $514 .{ }^{14}$ Drug data is consolidated from the Triadic Patents Families database, a separate OECD dataset (which lists all patents granted at the USPTO), and data from the USPTO Web site. The time variable used in all three instances is the patent grant year. Table 13 summarizes these findings. For the entire period, the discrepancy between the OECD and USPTO data is negligible. This reinforces confidence in the reliability of both these datasets, and justifies using them interchangeably. Ideally, when this information is compared to that from the Triadic Patent Families database, it should reveal the extent to which patents are applied in the United States, but not all three patent offices. In other words, a priori the "Triadic" series is expected to be smaller than the other two. Table 13 shows that: entries in the column " $1 \& 2$ " are all negative. However, it appears that the discrepancy between values is convincing only for the period 1988-1995. The large discrepancy in the more distant past (pre-1988) is probably because the EPO was newly set up, while the post-1995 data is incomplete ${ }^{15}$ for the "Triadic" database due to delays in the process of granting patents in the US. Indeed, the steep increase in the difference in both series between 1996 and 2000 seems implausible in a world environment where intellectual property rights have become more prominent.

Focusing then on the 1988 - 1995 period for further analysis, we see that starting from the late-1980s, an increasing number of drug patents have been applied at all three patent offices. By 1990, only $7 \%$ of patents were applied at the USPTO and not both the European and Japan patent offices. In fact, between 1988 and 1995, the average annual discrepancy was $-6 \%$, even though it registered a low $-1 \%$ in 1992 , and $-3 \%$ in both 1994 and 1995.

In view of the lags described above, any meaningful comparison between FDA approval and patent data should take these lags into account. In Table 14, we attempt to give a rough idea of the lags involved by listing the USPTO patent grant date and FDA approval date for 20 selected drugs. The data was obtained by doing a search (by proprietary name) on the FDA Electronic Orange Book database. ${ }^{16}$ We obtain, for each brand name, its patent number(s) and FDA approval date. Next, we use the patent number to search for patent information on the USPTO Web site. ${ }^{17}$ Note that there may be more than one patent number

14. The class name for these groups is "Drug, Bio-Affecting and Body Treating Compositions".

15. "Incomplete" refers to the delay in obtaining granting data. The fact that the original "Triadic" dataset selects patents of greatest significance (by design of the dataset) is not the issue here. Indeed, its construction is aimed at reducing the "noise" of the consolidated patent dataset, thus rendering more meaningful analyses.

16. www.fda.gov

17. www.uspto.gov 
associated with a particular application - we illustrate this for two of our drugs, namely Epivir and Hivid. ${ }^{18}$ The lag between a patent file date and its grant date is often around two years, while the lag between its grant date and FDA approval may be as short as 1 year (Hivid) or as long as 12 years (Lotrel). From our list of examples, the average lag is 6 years, with eight instances where the lag is between 6-8 years, and six cases where it is between 2 and 4 years. Care should be taken when interpreting these results. For one, our sample is very small and is possibly not representative of the lags that exist in the population of drugs. Essentially, the aim of our illustration is merely to highlight that lags do exist, and often vary between drugs.

18. Note that some of the other drugs in Table 14 may have more than one patent number, but we do not list them all. 
DSTI/DOC(2002)16

\section{SECTION 8. ANALYZING THE EFFECT OF R\&D ON PATENTS}

In the preceding sections, we explored the nature of health patents, in terms of inventor-origin, applicant type, and scope of international co-operation. In this final section, we review the role of R\&D on patents. Studies have shown that there is a strong relationship between R\&D efforts and patents. For instance, in a study of US manufacturing industries in 1976, Bounds et al (1984) estimate that the elasticity of patenting with respect to R\&D expenditure is about 0.37; Cockburn and Henderson (1998) obtain an elasticity estimate of 0.836 using a sample of 10 firms between 1980-1988. In addition, other studies have shown that health technology embodied in drugs have a significant impact on various health outcomes. ${ }^{19}$ Should R\&D in health technology, specifically pharmaceuticals, also reveal a strong relationship with drug patents at the country level, then such $R \& D$ efforts ought to be encouraged for their positive impact on health outcomes.

To this end, we concentrate on one aspect of health-related R\&D, namely R\&D in the pharmaceutical industry. Since pharmaceutical R\&D expenditure data is most widely available for the business enterprise sector, we further confine our analysis to this sector. ${ }^{20}$ Business enterprises include both private and public enterprises and institutions serving these enterprises. We have found that $76 \%$ of the applicants for Medical Preparations patents are from private enterprises (Section 6). Therefore, despite confining our analysis to this one sector, we do not compromise much in terms of the scale of the data employed. Note too that it is possible that some pharmaceutical R\&D may be undertaken by manufacturing firms for which this is not their main economic activity. ${ }^{21}$ However, data limitations would necessitate that we assume that the measurement errors arising from this occur randomly and would have a negligible impact on our results. $R \& D$ expenditure in business enterprises is further decomposed into five sources of funding, namely business enterprises, government, higher education, private non-profit organizations and from abroad. In general, the industry finances nearly all the R\&D it performs. Nonetheless, the decomposition could permit us to analyze the relative impact of the various R\&D funding sources. The ANBERD data series compiled by the OECD provides us with R\&D performed by industry across 19 OECD countries.

In order to compare $R \& D$ expenditure across both countries and time, we first convert all data to US purchasing power parity (PPP) dollars at 1995 constant prices. Evenson (1984) used a similar deflator in a

19. Using data from the 1997 Medical Expenditure Panel Survey, Lichtenberg and Virabhak (2002) calculate that the cost of the increase in drug vintage (measured using data on drug patent approvals) required to keep a person alive is lower than some estimates of the value of remaining alive for one month.

20. Note that health related $R \& D$ data for the remaining three sectors, namely government, higher education and private non-profit sector, are in terms of total intramural R\&D for medical sciences or by socioeconomic objective. In addition, the level of detail of data provided varies widely across countries. These data limitations further strengthen our case to focus on business enterprises and in particular, the pharmaceutical industry within it.

21. In the industry group approach, the $R \& D$ of each enterprise is allocated to the industry of its main economic activity. Exceptions exist for large enterprises with several distinct economic activities. In these instances, R\&D may be divided between these activities. Cross-classifications of BERD between industry and product fields reveal information about R\&D undertaken outside the core industries. However, since all countries do not submit decomposition by product field, we cannot adjust for this discrepancy in the ensuing analysis. 
multi-country analysis. Although the real costs of conducting research may not be closely related to that of producing goods, we do not have an ideal deflator for R\&D spending in any single country, let alone one that would achieve cross-country comparability. Jaffe (1972) proposed an R\&D price index as a weighted sum of the implicit deflator for business sector output and an index of average business sector wages (see also Coe and Helpman (1995)). Due to lack of data for the former, we are not able to employ this alternative. Hence, we use implicit GDP deflators, along with PPP measures published by the OECD. We abstract from the Triadic Patent Family dataset drug patents (i.e. patents corresponding to USPC 424 and 514) between 1988-1995. We then consolidate the data according to drug patents obtained by country and year. Last, we combine this drug patent data with the abovementioned R\&D series.

We first assume a model where patents are an indicator of knowledge increment, which in turn is a function of current and lagged values of R\&D contributions (refer to Pakes and Griliches (1984) for details). This translates to an econometric model with a distributed lag that describes the impact business enterprise $R \& D$ expenditure on patents in the pharmaceutical industry of the form:

$$
\text { Patent }_{i, t}=a_{i}+b_{1} R D i_{, t}+b_{2} R D_{i, t-1}+\ldots+b_{3} R D_{i, t-n}+c t
$$

where Patent $\mathrm{i}_{\mathrm{i}, \mathrm{t}}$ is the logarithm of the number "important drug patents" ${ }^{, 2}$ obtained by country i in yeart, ${ }^{23}$ $\mathrm{RD}_{\mathrm{i}, \mathrm{t}}$ measures the logarithm of total business enterprise pharmaceutical $R \& D$ expenditure by country $i$ in year $t ; n$ is the number of lags; $t$ is the time trend that would control for aggregate trend; and $a_{i}$ measures country effect. We propose the random effect approach, which specifies that $a_{i}$ is a group specific disturbance. This seems appropriate as we have a sample of cross-sectional units drawn from a large population. As such, it may be more accurate to view individual specific constant terms as randomly distributed across cross-sectional units, rather than as parametric shifts of the regression function (i.e. as in the fixed effects model). We subsequently apply the random effects model to all our regressions. ${ }^{24}$

Due to missing data, we have an unbalanced panel. In fact, for the period 1988-1995, only 13 of the 19 countries $^{25}$ have complete data for pharmaceutical-related $R \& D$ expenditure in business enterprises. When we apply (1) to include four lags $(n=4)$, the number of observations used in the regression is reduced to only 53 , and the coefficient estimate for $\mathrm{RD}_{\mathrm{i}, \mathrm{t}}$ is negative with a $\mathrm{p}$-value of 0.65 . $^{26}$ The lag values of $R \& D$ are also insignificant, except the case where $n=4$. We report these results as Model 1 in Table 15. A very likely reason for this result is the lack of data points: we have an 8-year interval across 13 countries

22. Patents in the Triadic Patent Family are by default "important", meaning that they have been granted or applied in major markets (US, Japan and EU). In other studies, "important patents" have been defined as those granted in at least 2 of the 3 markets. See for instance Cockburn and Henderson $(1996,1998)$.

23. As noted by Cockburn and Henderson (1998), the economic value of patents is skewed, whereas patent counts, which are employed here, are consistently measured across time and are closely linked to research activity.

24. When country effects are random, observations are assumed to be uncorrelated within this effect. However, by including a lagged variable(s) in the regression, we allow correlations between observations within a country. Note too that firm level studies have suggested that patent counts are generated by a Poisson process, which is appropriate if research results are modeled as the outcome of an unknown but large number of Bernoulli trials with a small probability of success. While this captures some features of drug research, our present analysis is at the country level aggregate, which may make such an application less probable.

25. They include Australia, Canada, Denmark, Finland, France, Ireland, Japan, Netherlands, Norway, Spain, Sweden, UK and US.

26. Using 3 lags instead increases the number of observations to 68 but does not improve the significance of the $\mathrm{RD}_{\mathrm{i}, \mathrm{t}}$ variable. 
and a finite distributed lag form of (1). To overcome this problem, we make the reasonable assumption that we have an infinite distributed lag model. This implies that $\mathrm{n}$ goes to infinity. The computational advantage of doing this is that we can re-express the model in the autoregressive form (see Greene (1993)):

$$
\text { Patent }_{\mathrm{i}, \mathrm{t}}=\mathrm{a}(\mathrm{i})+\mathrm{b}_{0} \text { Patent }_{\mathrm{i}, \mathrm{t}-1}+\mathrm{b}_{1} \mathrm{RD}_{\mathrm{i}, \mathrm{t}}+\mathrm{b}_{2} \mathrm{Gov}+\mathrm{c}(\mathrm{t})
$$

Recall from the initial discussion that we had intended to decipher the impact of the different sources of R\&D funding. It turns out that the relevant series is fraught with missing entries. Here, we overcome this limitation by constructing a covariate, Gov, which is included in our construction of (2). Gov is a measure of the degree of governmental contribution to pharmaceutical business enterprise R\&D. ${ }^{27} \mathrm{We}$ assume for simplicity a linear time trend. Model 2 (Table 15) presents the results from estimating this model. The RD coefficient is positive and highly significant, with an elasticity of 1.25 , whereas the elasticity of lag patent is positive but inelastic. The covariate Gov is significant at $2 \%$.

Rather than analyzing the dynamics of the $R \& D$ relationship by estimating the lag structures of input variables, ${ }^{28}$ we now turn to an alternative employed by numerous other studies, including Cockburn and Henderson $(1996,1998)$, which include "stocks" of input variables as explanatory variables. We assume instead that the stock of patents accumulated to time T reflects the stock of knowledge accumulated via R\&D. This specification has greater intuitive appeal compared to (2), and is expressed as: ${ }^{29}$

$$
\text { Patent }_{\mathrm{i}, \mathrm{t}}=\mathrm{a}(\mathrm{i})+\mathrm{b}_{0} \text { PatentStock }_{\mathrm{i}, \mathrm{t}-1}+\mathrm{b}_{1} \mathrm{RD}_{\mathrm{i}, \mathrm{t}}+\mathrm{b}_{2} \mathrm{Gov}+\mathrm{ct}
$$

where PatentStock $\mathrm{i}_{\mathrm{i}, \mathrm{-}-1}$ is the stock of patents accumulated up to time $\mathrm{t}-1$. Model 3 presents the results without the covariate Gov. First, note that the fit of the model is improved under this specification. ${ }^{30}$ The R\&D as well as patent stock variables are very significant, and are both inelastic, although the former is less elastic at 0.43 as opposed to 0.79 for the latter. ${ }^{31}$ This confirms the widely held view that the ease of obtaining patents depends positively on current R\&D spending as well as the stock of knowledge (reflected

27. To construct this covariate, we first compute the proportion of business enterprise R\&D financed by the government for available data points. We pool 4-year averages in order to reduce the set of missing entries. Last, we group countries into those in which the government contributes less than 5\%, and more than and including $5 \%$ of total business enterprise R\&D. Due to missing entries in some countries, we classify all missing entries into a third category. The frequency distribution of Gov is given by:

\begin{tabular}{|ccc|}
\hline Gov & Freq & Percent \\
\hline 0 & 84 & $43.75 \%$ \\
1 & 32 & $16.67 \%$ \\
9 & 76 & $39.58 \%$ \\
\hline
\end{tabular}

Note that we made an alternative hypothesis that the level of government spending matters, rather than the percentage. Using the methodology above, we constructed a covariate (with a similar frequency distribution to Gov) that reflected high and low levels of government expenditure. In regressions using this alternative measure of governmental involvement, we consistently obtained a worse fit of the model; in addition, the covariate failed to be significant.

28. We have already witnessed some of the disadvantages of using lags, which include having to make assumptions about distributed lags, and throwing out much data in order to have say, four lags present for each observation.

29. (3) can be looked upon as a distributed lag on the dependent variable.

30. When we ran a model using fixed country effects, we obtained a very high R-square value of over 0.9.

31. In their study of 10 firms, Cockburn and Henderson (1998) also obtained an inelastic R\&D coefficient estimate and a relatively higher elasticity for past patent stock. 
by past patent stock). Finally, Model 4 includes our covariate Gov. The fit of the model is enhanced, as is the significance of the $R \& D$ variable. While both contemporaneous $R \& D$ expenditure and past patent stock remain inelastic, they have almost similar elasticities under this final specification (0.66). Gov has an overall significance of $2 \%$. Relative to the category of missing entries, government finance in country-year observations with a low level of government involvement enhance patent attainment. However, the reverse holds (although significant only at 12\%) for government funding in instances where government involvement was higher. This may reflect a crowding out effect of government funding, but given the scant data from which we constructed this covariate, it would certainly be premature to draw further conclusions. Nonetheless, exploring the impact of public versus private funding of business enterprise R\&D appears to be a worthwhile endeavor once this data becomes available.

Using patent data as well as data on R\&D expenditure, we construct an empirical model that describes the impact of business enterprise pharmaceutical $R \& D$ expenditure on patent acquisition across OECD countries. Our empirical results confirm a widely held belief that R\&D has a significant and positive impact on patents. In particular, we obtain an R\&D elasticity of 0.43 . Further, our model supports the claim that accumulated knowledge, captured by the patent stock variable, is also an important determinant (elasticity of 0.79 ). Although the current dataset does not allow us to examine the impact of public and private $\mathrm{R} \& \mathrm{D}$ funding, this would be an interesting extension once the necessary data becomes available. 
DSTI/DOC(2002)16

\section{REFERENCES}

Bound, John, Cummins, Clint, Griliches, Zvi, Hall, H. Bronwyn, and Adam Jaffe (1984), "Who Does R\&D and Who Patents?" in Griliches, Zvi (ed.), R\&D, Patents, and Productivity, University of Chicago Press, Chicago and London, pp. 21-24.

Cockburn, Iain M. and Rebecca M. Henderson (1998), "Absorptive Capacity, Coauthoring Behavior, and the Organization of Research in Drug Discovery", The Journal of Industrial Economics, vol. XLVI, No. 2, pp. 157-182.

Coe, David T. and Elhanan Helpman (1995), "International R\&D Spillovers", European Economic Review 39, pp. 859-887.

Evenson, Robert E. (1984), "International Invention: Implications for Technology Market Analysis" in Griliches, Zvi (ed.), R\&D, Patents, and Productivity, University of Chicago Press, Chicago and London, pp. 89-126.

Greene, William H. (1997), Econometric Analysis, third edition, Prentice Hall Inc., New Jersey.

Henderson, Rebecca and Iain Cockburn (1996), "Scale, Scope and Spillovers: The Determinants of Research Productivity in Drug Discovery”, RAND Journal of Economics, vol.27, No.1, pp. 32-59.

Jaffe, S.A. (1972), A Price Index for deflation of Academic R\&D Expenditures, National Institute of Education, Washington, D.C.

Lichtenberg F. and S. Suchin (2002), Pharmaceutical Embodied Technical Progress, Longevity and Quality of Life: Drugs as "Equipment for Your Health", NBER Working Paper 9351, NBER, Cambridge, MA.

OECD (2001), Measuring Expenditure on Health-Related R\&D, OECD, Paris.

OECD (2002), Basic Science and Technology Indicators, annual publication, OECD Paris.

Pakes, Ariel and Griliches, Zvi (1984), "Patents and R\&D at the Firm Level: A First Look" in Griliches, Zvi (ed.), R\&D, Patents, and Productivity, University of Chicago Press, Chicago and London, pp. 55-72. 


\section{APPENDIX A: PATENTS ASSOCIATED WITH HEALTH TECHNOLOGY - IPC A61 ${ }^{32}$}

\section{SECTION A - HUMAN NECESSITIES}

HEALTH; AMUSEMENT

\section{A 61 MEDICAL OR VETERINARY SCIENCE; HYGIENE}

\section{A61B (SURGERY) $)^{33}$}

DIAGNOSIS; SURGERY; IDENTIFICATION (analyzing biological material G01N, e.g. G01N 33/48; obtaining records using waves other than optical waves, in general G03B 42/00).

\section{A61C (DENTISTRY)} $6 / 00)$.

DENTISTRY; ORAL OR DENTAL HYGIENE (tooth brushes A46B; preparations for dentistry A61K A61D

VETERINARY INSTRUMENTS, IMPLEMENTS, TOOLS, OR METHODS.

\section{A61F (PROSTHESES ETC.)}

FILTERS IMPLANTABLE INTO BLOOD VESSELS; PROSTHESES; ORTHOPAEDIC, NURSING OR CONTRACEPTIVE DEVICES; FOMENTATION; TREATMENT OR PROTECTION OF EYES OR EARS; BANDAGES, DRESSINGS OR ABSORBENT PADS; FIRST-AID KITS (dental prosthetics A61C) [6].

\section{A61G (TRANSPORT/ACCOM.)}

TRANSPORT OR ACCOMMODATION FOR PATIENTS; OPERATING TABLES OR CHAIRS; CHAIRS FOR DENTISTRY; FUNEREAL DEVICES (chairs or beds in general A47C; walking aids A61H $3 / 00)$.

\footnotetext{
32 Our analysis excludes patents from class A61D. The IPC schedule is available on several Web sites, including the one used here from the World Intellectual Property Organization:

http://www.wipo.int/classifications/fulltext/new_ipc/ipc7/ea61.htm 


\section{A61H (PT DEVICES ETC.)}

PHYSICAL THERAPY APPARATUS, e.g. DEVICES FOR LOCATING OR STIMULATING REFLEX POINTS IN THE BODY; ARTIFICIAL RESPIRATION; MASSAGE; BATHING DEVICES FOR SPECIAL THERAPEUTIC OR HYGIENIC BODY (methods or devices enabling invalids to operate an apparatus or a device not forming part of the body A61F 4/00; electrotherapy, magnetotherapy, radiation therapy, ultrasound therapy A61N).

\section{A61J (CONTAINERS ETC.)}

CONTAINERS SPECIALLY ADAPTED FOR MEDICAL OR PHARMACEUTICAL PURPOSES; DEVICES OR METHODS SPECIALLY ADAPTED FOR BRINGING PHARMACEUTICAL PRODUCTS INTO PARTICULAR PHYSICAL OR ADMINISTERING FORMS; DEVICES FOR ADMINISTERING FOOD OR MEDICINES ORALLY; BABY COMFORTERS; DEVICES FOR RECEIVING SPITTLE.

\section{A61K (MEDICAL PREPARATIONS)}

PREPARATIONS FOR MEDICAL, DENTAL, OR TOILET PURPOSES (bringing into special physical form A61J; chemical aspects of, or use of materials for deodorization of air, for disinfection or sterilization, or for bandages, dressings, absorbent pads or surgical articles A61L; compounds per se C01, C07, C08, C12N; soap compositions C11D; micro-organisms per se C12N).

\section{A61L (STERILIZATION)}

METHODS OR APPARATUS FOR STERILISING MATERIALS OR OBJECTS IN GENERAL; DISINFECTION, STERILISATION, OR DEODORISATION OF AIR; CHEMICAL ASPECTS OF BANDAGES, DRESSINGS, ABSORBENT PADS, OR SURGICAL ARTICLES; MATERIALS FOR BANDAGES, DRESSINGS, ABSORBENT PADS, OR SURGICAL ARTICLES (preservation of bodies or disinfecting characterized by the agent employed A01N; preserving, e.g. sterilizing, food or foodstuffs A23; preparations for medical, dental or toilet purposes A61K; preparation of ozone C01B 13/10) [4].

\section{A61M (MEDIA DEVICES)}

DEVICES FOR INTRODUCING MEDIA INTO, OR ONTO, THE BODY (introducing media into or onto the bodies of animals A61D 7/00; means for inserting tampons A61F 13/26; devices for administering food or medicines orally A61J; containers for collecting, storing or administering blood or medical fluids A61J 1/05); DEVICES FOR TRANSDUCING BODY MEDIA OR FOR TAKING MEDIA FROM THE $B O D Y$ (Surgery A61B; chemical aspects of surgical articles A61L; magnetotherapy using magnetic elements placed within the body A61N 2/10); DEVICES FOR PRODUCING OR ENDING SLEEP OR STUPOR [4,5].

\section{A61N (ELECTROTHERAPY ETC.)}

ELECTROTHERAPY; MAGNETOTHERAPY; RADIATION THERAPY; ULTRASOUND THERAPY (measurement of bioelectric currents A61B; surgical instruments, devices or methods for transferring nonmechanical forms of energy to or from the body A61B 18/00; anaesthetic apparatus in general A61M; incandescent lamps H01K; infra-red radiators for heating H05B) [6].

\section{A61P (CHEMICAL COMPOUNDS)}

THERAPEUTIC ACTIVITY OF CHEMICAL COMPOUNDS OR MEDICINAL PREPARATIONS [7]. 


\title{
APPENDIX B: DETAILS OF HEALTH TECHNOLOGY CLASS IPC A61K
}

\author{
A61K PREPARATIONS FOR MEDICAL, DENTAL OR TOILET PURPOSES
}

\section{A61K6/00}

Preparations for dentistry (teeth cleaning preparations A61K7/16; dentistry A61C).

\section{A61K7/00}

Cosmetics or similar toilet preparations (casings or accessories for storing or handling of solid or pasty toilet or cosmetic substances A45D40/00).

\section{A61K9/00}

Medicinal preparations characterized by special physical form (preparations containing radioactive substances A61K51/12) [C9803].

\section{A61K31/00}

Medicinal preparations containing organic active ingredients.

\section{A61K33/00}

Medicinal preparations containing inorganic active ingredients.

\section{A61K35/00}

Medicinal preparations containing material or reaction products thereof with undetermined constitution.

\section{A61K38/00}

Medicinal preparations containing peptides (peptides containing beta-lactam rings A61K31/00; cyclic dipeptides not having in their molecule any other peptide link than those which form their ring, e.g. piperazine-2,5-diones, A61K31/00; ergot alkaloids of the cyclic peptide type A61K31/48; containing macromolecular compounds having statistically distributed amino acid units A61K31/74; medicinal preparations containing antigens or antibodies A61K39/00; medicinal preparations characterized by the non-active ingredients, e.g. peptides as drug carriers, A61K47/00) [N9412].

\section{A61K39/00}

Medicinal preparations containing antigens or antibodies (materials for immunoassay G01N33/53) [C9805]. 


\section{A61K41/00}

Medicinal preparations obtained by treating materials with wave energy or particle radiation; [N: Therapies using these preparations] (A61K31/59 takes precedence; generation of ultrasonic waves B06B; electric discharge tubes H01J) [C9701].

\section{A61K45/00}

Medicinal preparations containing active ingredients not provided for in groups A61K31/00 to A61K41/00.

\section{A61K47/00}

Medicinal preparations characterized by the non-active ingredients used, e.g. carriers, inert additives, [N: e.g. penetration enhancers, solvents, stabilizers].

\section{A61K48/00}

Medicinal preparations containing genetic material which is inserted into cells of the living body to treat genetic diseases; Gene therapy.

\section{A61K49/00}

Preparations for testing.

\section{A61K51/00}

Preparations containing radioactive substances for use in therapy or testing in vivo. 


\section{APPENDIX C: CONSOLIDATING HEALTH PATENT APPLICANT NAMES}

In general, key phrases are used to search for applicants corresponding to each category. Results were then checked at each stage and further refinements made. This was done repeatedly until a fairly well sorted dataset was obtained. For instance, a private company is likely to have one of the following phrases/expressions in its name: Co., Corp., AB, AG, LLC, PLC, SPA, SRL, Ltd., just to name a few. In addition, there are a fair number of entries for which the names of the same company is not consistently recorded, and if the name is recongizeable and the inconsistency is a certainty, the entry is reclassified accordingly. By checking all the entries, we are most confident of our results for "University" and "Medical". Although applicants listed as "Company" are correctly placed, some may have been left out and these in turn might have been mis-categorized in either "Other" or "Research", although the nature of the search methodology makes the former more likely.

It is important to note that in the category of "Company" research firms that are private corporations are included. However, for educational institutions ("University") and medical institutions like hospitals ("Medical"), whether or not they are private or publicly run is ignored. The category "Public" is made up of applicants from government bodies or departments, or ministries. Other research organizations that are not clearly private are grouped into "Research". The motivation for creating this category is the fact that many applicants come from clearly non-commercial organizations that are involved in research and development. Furthermore, for a group of these applicants, it is not obvious if they are partially or completely (or not at all) financed publicly - hence the reluctance to place them under "Public". The last category, "Other" has all residual applicants - this includes applicant names for which it is difficult to decipher the nature of the applicant type, and includes individuals as well. 


\section{TABLES}

Table 1. Health patents by technology class, 1988-1995

\begin{tabular}{|lrr|}
\hline Technology class & No. of patents & $\%$ patents \\
\hline Medical preparations & 23577 & $58.4 \%$ \\
Surgery & 5419 & $13.4 \%$ \\
Media devices & 3844 & $9.5 \%$ \\
Prostheses & 3740 & $9.3 \%$ \\
Sterilization & 1276 & $3.2 \%$ \\
Electrotherapy etc. & 1083 & $2.7 \%$ \\
Dentistry & 756 & $1.9 \%$ \\
Transport/Accom. & 247 & $0.6 \%$ \\
Containers etc. & 236 & $0.6 \%$ \\
PT devices & 175 & $0.4 \%$ \\
Chemical compounds & 14 & $0.0 \%$ \\
\hline Total & 40367 & $100.0 \%$ \\
\hline
\end{tabular}

Source: OECD Database of Triadic Patent Family. 
Table 2. Health patents by OECD country of inventor, all years

\begin{tabular}{|lrc|}
\hline Country & $\begin{array}{c}\text { No. of health } \\
\text { patents } \text { (wted) }\end{array}$ & $\begin{array}{c}\text { \% World } \\
\text { health } \\
\text { patents }\end{array}$ \\
\hline US & 22409.4 & $55.75 \%$ \\
EU & 10810.1 & $26.90 \%$ \\
Japan & 4292.2 & $10.68 \%$ \\
Germany & 3030.5 & $7.54 \%$ \\
France & 2301.1 & $5.72 \%$ \\
UK & 2225.5 & $5.54 \%$ \\
Sweden & 1024.3 & $2.55 \%$ \\
Switzerland & 759.5 & $1.89 \%$ \\
Italy & 716.6 & $1.78 \%$ \\
Canada & 684.2 & $1.70 \%$ \\
Netherlands & 448.2 & $1.12 \%$ \\
Denmark & 311.6 & $0.78 \%$ \\
Belgium & 243.0 & $0.60 \%$ \\
Australia & 224.3 & $0.56 \%$ \\
Austria & 212.5 & $0.53 \%$ \\
Spain & 124.2 & $0.31 \%$ \\
Finland & 121.6 & $0.30 \%$ \\
Norway & 97.5 & $0.24 \%$ \\
Korea & 80.3 & $0.20 \%$ \\
Hungary & 58.3 & $0.15 \%$ \\
Ireland & 39558.6 & $98.42 \%$ \\
New Zealand & 57.0 & $0.14 \%$ \\
Czech Rep. & 31.4 & $0.08 \%$ \\
Poland & 20.4 & $0.05 \%$ \\
Mexico & 17.2 & $0.04 \%$ \\
Iceland & 15.4 & $0.04 \%$ \\
Greece & 6.5 & $0.02 \%$ \\
Turkey & 3.6 & $0.01 \%$ \\
Portugal & 3.5 & $0.01 \%$ \\
Slovak Rep. & 1.4 & $0.00 \%$ \\
Luxembourg & 1.2 & $0.00 \%$ \\
\hline OECD & 0.7 & $0.00 \%$ \\
\hline
\end{tabular}

Source: OECD Database of Triadic Patent Family. 
DSTI/DOC(2002)16

Table 3. Trend in health patent inventor origin across OECD countries

\begin{tabular}{|c|c|c|c|c|c|c|c|}
\hline \multirow[b]{2}{*}{ Country } & \multicolumn{6}{|c|}{ Number of Patents (wted) } & \multirow[b]{2}{*}{ Chg rank ${ }^{1}$} \\
\hline & 1988-1989 & Rank & 1990-1992 & Rank & 1993-1995 & Rank & \\
\hline US & 4757.4 & 1 & 7771.4 & 1 & 9880.6 & 1 & 0 \\
\hline Japan & 1336.7 & 2 & 1637.5 & 2 & 1318.0 & 2 & 0 \\
\hline Germany & 817.7 & 3 & 1153.7 & 3 & 1059.1 & 3 & 0 \\
\hline France & 481.1 & 5 & 835.2 & 5 & 984.8 & 4 & 1 \\
\hline UK & 647.4 & 4 & 884.3 & 4 & 693.8 & 5 & -1 \\
\hline Sweden & 202.2 & 7 & 382.8 & 6 & 439.2 & 6 & 1 \\
\hline Canada & 147.8 & 9 & 242.6 & 9 & 293.9 & 7 & 2 \\
\hline Switze rland & 198.5 & 8 & 302.2 & 8 & 258.8 & 8 & 0 \\
\hline Italy & 219.7 & 6 & 312.7 & 7 & 184.1 & 9 & -3 \\
\hline Netherlands & 109.1 & 10 & 173.6 & 10 & 165.6 & 10 & 0 \\
\hline Denmark & 75.3 & 11 & 129.4 & 11 & 106.9 & 11 & 0 \\
\hline Belgium & 58.5 & 13 & 100.0 & 12 & 84.5 & 12 & 1 \\
\hline Austria & 59.5 & 12 & 72.4 & 14 & 80.6 & 13 & -1 \\
\hline Australia & 55.2 & 14 & 88.7 & 13 & 80.4 & 14 & 0 \\
\hline Korea & 10.7 & 19 & 14.4 & 21 & 55.2 & 15 & 4 \\
\hline Finland & 31.3 & 16 & 40.4 & 16 & 49.9 & 16 & 0 \\
\hline Spain & 22.4 & 17 & 55.5 & 15 & 46.3 & 17 & 0 \\
\hline Ireland & 7.2 & 21 & 17.0 & 20 & 32.8 & 18 & 3 \\
\hline Norway & 32.4 & 15 & 34.0 & 17 & 31.1 & 19 & -4 \\
\hline Hungary & 14.7 & 18 & 28.0 & 18 & 15.6 & 20 & -2 \\
\hline New Zealand & 0.4 & 25 & 19.5 & 19 & 11.5 & 21 & 4 \\
\hline Poland & 3.1 & 22 & 5.1 & 24 & 9.1 & 22 & 0 \\
\hline Mexico & 2.0 & 23 & 5.3 & 23 & 8.1 & 23 & 0 \\
\hline Czech Rep. & 8.4 & 20 & 8.6 & 22 & 3.4 & 24 & -4 \\
\hline Iceland & 0.0 & 26 & 4.0 & 25 & 2.5 & 25 & 1 \\
\hline Greece & 0.0 & 26 & 2.4 & 27 & 1.2 & 26 & 0 \\
\hline Turkey & 1.0 & 24 & 2.5 & 26 & 0.0 & 27 & -3 \\
\hline$O E C D$ & 9305.4 & & 14337.6 & & 15915.6 & & \\
\hline
\end{tabular}

Note: $\quad$ Greece, Luxembourg, Portugal and Slovak Rep. were not significant players, and they are excluded so that differences in rankings would be easier to interpret (no ties).

Source: $\quad$ OECD Database of Triadic Patent Family.

1. Change in rank between 1988-89 and 1993-95. 


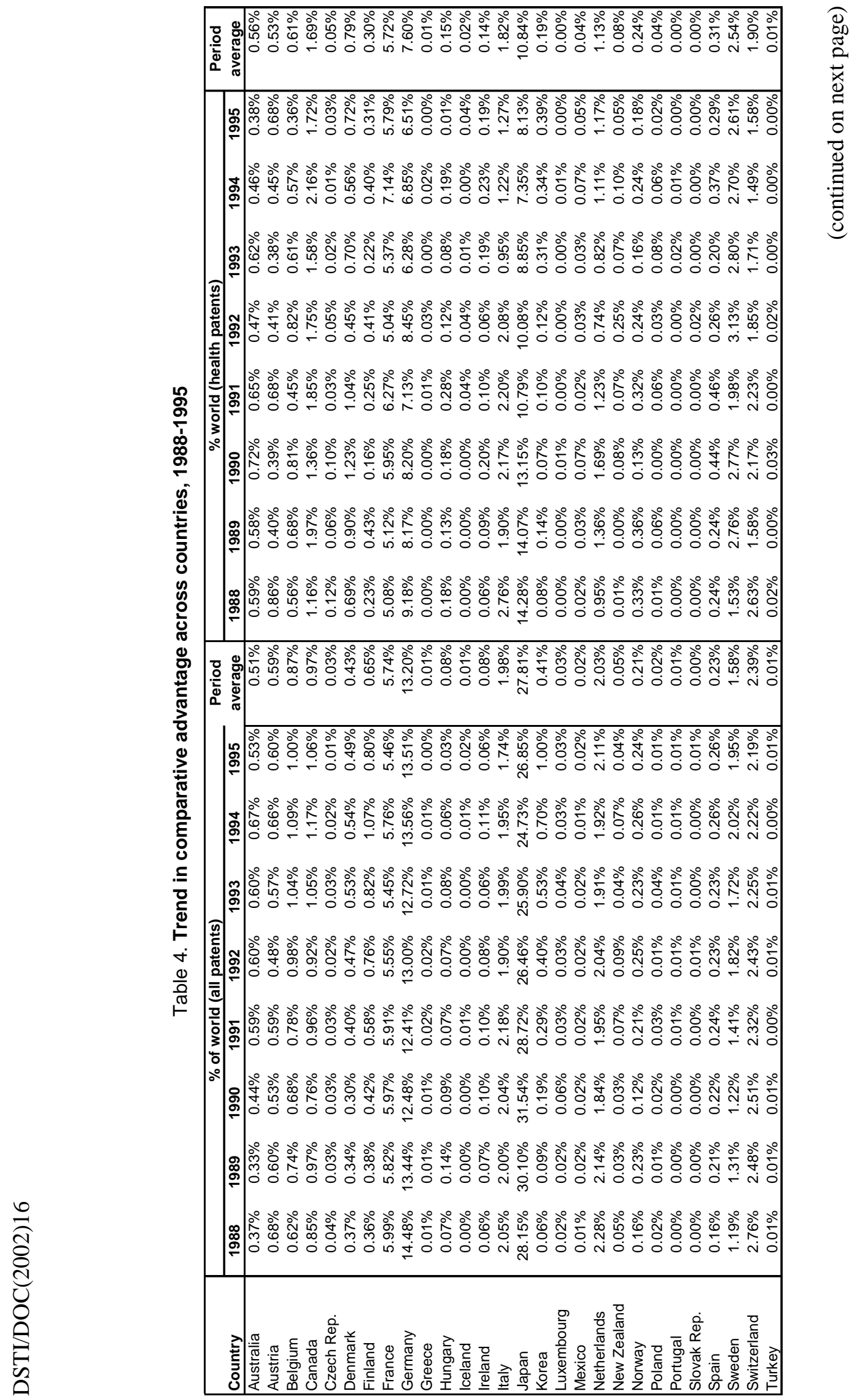




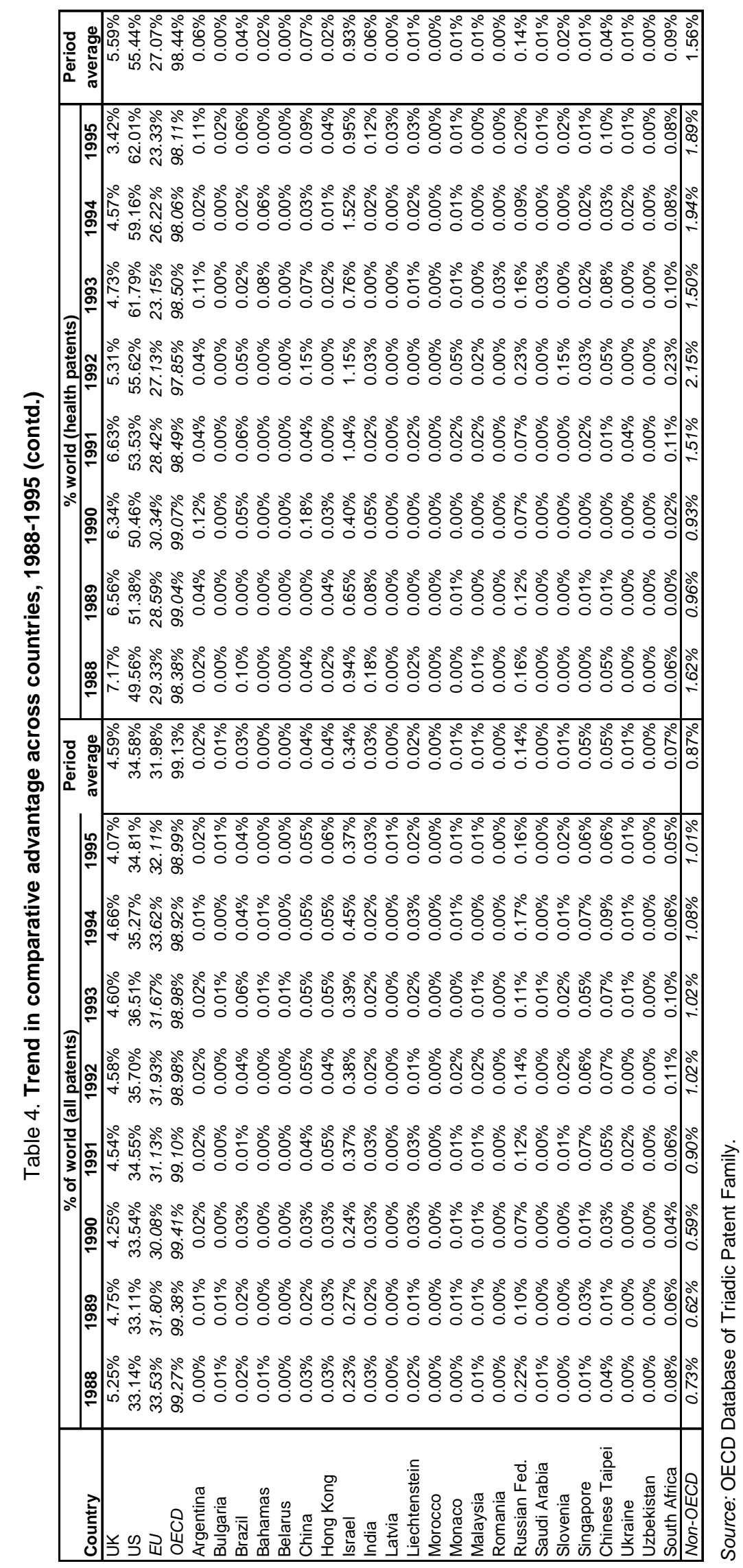


Table 5. Distribution of international co-operation by health technology type

\begin{tabular}{|llll|}
\hline Technology & \% total (inv) & Rank (inv) & Rank (number) \\
\hline Medical preparations & $70.8 \%$ & 1 & 1 \\
Prostheses etc. & $8.7 \%$ & 2 & 4 \\
Surgery & $8.2 \%$ & 3 & 2 \\
Media devices & $5.9 \%$ & 4 & 3 \\
Sterilization & $2.2 \%$ & 5 & 5 \\
Electrotherapy etc. & $2.0 \%$ & 6 & 6 \\
Dentistry & $1.3 \%$ & 7 & 7 \\
\hline
\end{tabular}

Source: OECD Database of Triadic Patent Family.

Table 6. Trend in international co-operation in selected health technologies

\begin{tabular}{|l|ccr|}
\hline Technology class & Year & $\begin{array}{c}\text { No. shared } \\
\text { inventions }\end{array}$ & $\begin{array}{r}\text { Share of } \\
\text { patents }\end{array}$ \\
\hline & $1988-1989$ & 588 & $9.8 \%$ \\
Medical preparations & $1990-1992$ & 987 & $11.3 \%$ \\
& $1993-1995$ & 1007 & $11.4 \%$ \\
\hline Prostheses etc. & $1988-1989$ & 43 & $4.2 \%$ \\
& $1990-1992$ & 136 & $6.9 \%$ \\
& $1993-1995$ & 119 & $4.9 \%$ \\
\hline Surgery & $1988-1989$ & 46 & $6.0 \%$ \\
& $1990-1992$ & 104 & $7.4 \%$ \\
Media devices & $1993-1995$ & 168 & $10.1 \%$ \\
\hline
\end{tabular}

Source: OECD Database of Triadic Patent Family. 
DSTI/DOC(2002)16

Table 7. Trend in international co-operation in health technology R\&D

\begin{tabular}{|c|c|c|c|c|c|}
\hline \multirow{2}{*}{ Country } & \multicolumn{3}{|c|}{ Year } & \multicolumn{2}{|c|}{$\%$ chg } \\
\hline & 1: 1988-1989 & 2: 1990-1992 & 3: 1993-1995 & $1 \& 2$ & $2 \& 3$ \\
\hline Australia & $34.78 \%$ & $38.58 \%$ & $24.59 \%$ & $11 \%$ & $-36 \%$ \\
\hline Austria & $24.64 \%$ & $37.23 \%$ & $38.14 \%$ & $51 \%$ & $2 \%$ \\
\hline Belgium & $33.80 \%$ & $43.08 \%$ & $49.58 \%$ & $27 \%$ & $15 \%$ \\
\hline Canada & $23.98 \%$ & $39.12 \%$ & $32.96 \%$ & $63 \%$ & $-16 \%$ \\
\hline Czech Rep. & $41.67 \%$ & $57.14 \%$ & $90.91 \%$ & $37 \%$ & $59 \%$ \\
\hline Denmark & $20.00 \%$ & $32.91 \%$ & $29.55 \%$ & $65 \%$ & $-10 \%$ \\
\hline Finland & $34.15 \%$ & $37.25 \%$ & $33.87 \%$ & $9 \%$ & $-9 \%$ \\
\hline France & $16.73 \%$ & $21.36 \%$ & $17.45 \%$ & $28 \%$ & $-18 \%$ \\
\hline Germany & $19.67 \%$ & $23.31 \%$ & $26.51 \%$ & $19 \%$ & $14 \%$ \\
\hline Greece & $\mathrm{n} / \mathrm{a}$ & $85.71 \%$ & $66.67 \%$ & $\mathrm{n} / \mathrm{a}$ & $-22 \%$ \\
\hline Hungary & $40.00 \%$ & $0.00 \%$ & $54.55 \%$ & $-100 \%$ & $\mathrm{n} / \mathrm{a}$ \\
\hline Iceland & $\mathrm{n} / \mathrm{a}$ & $0.00 \%$ & $33.33 \%$ & $\mathrm{n} / \mathrm{a}$ & $\mathrm{n} / \mathrm{a}$ \\
\hline Ireland & $71.43 \%$ & $79.31 \%$ & $57.45 \%$ & $11 \%$ & $-28 \%$ \\
\hline Italy & $15.79 \%$ & $19.43 \%$ & $31.25 \%$ & $23 \%$ & $61 \%$ \\
\hline Japan & $6.71 \%$ & $8.31 \%$ & $12.63 \%$ & $24 \%$ & $52 \%$ \\
\hline Korea & $23.08 \%$ & $27.78 \%$ & $30.00 \%$ & $20 \%$ & $8 \%$ \\
\hline Luxembourg & $\mathrm{n} / \mathrm{a}$ & $100.00 \%$ & $100.00 \%$ & $\mathrm{n} / \mathrm{a}$ & $0 \%$ \\
\hline Mexico & $75.00 \%$ & $33.33 \%$ & $100.00 \%$ & $-56 \%$ & $200 \%$ \\
\hline Netherlands & $33.10 \%$ & $25.12 \%$ & $33.66 \%$ & $-24 \%$ & $34 \%$ \\
\hline New Zealand & $100.00 \%$ & $14.29 \%$ & $33.33 \%$ & $-86 \%$ & $133 \%$ \\
\hline Norway & $40.48 \%$ & $65.96 \%$ & $52.27 \%$ & $63 \%$ & $-21 \%$ \\
\hline Poland & $71.43 \%$ & $60.00 \%$ & $70.59 \%$ & $-16 \%$ & $18 \%$ \\
\hline Portugal & $\mathrm{n} / \mathrm{a}$ & $\mathrm{n} / \mathrm{a}$ & $50.00 \%$ & $\mathrm{n} / \mathrm{a}$ & $\mathrm{n} / \mathrm{a}$ \\
\hline Slovak Rep. & $\mathrm{n} / \mathrm{a}$ & $100.00 \%$ & $\mathrm{n} / \mathrm{a}$ & $\mathrm{n} / \mathrm{a}$ & $\mathrm{n} / \mathrm{a}$ \\
\hline Spain & $54.29 \%$ & $23.88 \%$ & $44.44 \%$ & $-56 \%$ & $86 \%$ \\
\hline Sweden & $16.13 \%$ & $23.33 \%$ & $20.85 \%$ & $45 \%$ & $\mathrm{n} / \mathrm{a}$ \\
\hline Switzerland & $30.93 \%$ & $48.07 \%$ & $48.04 \%$ & $55 \%$ & $0 \%$ \\
\hline Turkey & $100.00 \%$ & $75.00 \%$ & $\mathrm{n} / \mathrm{a}$ & $-25 \%$ & $\mathrm{n} / \mathrm{a}$ \\
\hline UK & $19.80 \%$ & $33.96 \%$ & $36.57 \%$ & $71 \%$ & $8 \%$ \\
\hline us & $9.23 \%$ & $10.53 \%$ & $10.41 \%$ & $14 \%$ & $-1 \%$ \\
\hline$E U$ & $11.79 \%$ & $17.60 \%$ & $20.24 \%$ & $49 \%$ & $15 \%$ \\
\hline$O E C D$ & $13.69 \%$ & $17.34 \%$ & $17.06 \%$ & $27 \%$ & $-2 \%$ \\
\hline Argentina & $75.00 \%$ & $30.00 \%$ & $21.43 \%$ & $-60 \%$ & $-29 \%$ \\
\hline Bulgaria & $\mathrm{n} / \mathrm{a}$ & $\mathrm{n} / \mathrm{a}$ & $0.00 \%$ & $\mathrm{n} / \mathrm{a}$ & $\mathrm{n} / \mathrm{a}$ \\
\hline Brazil & $33.33 \%$ & $86.96 \%$ & $44.44 \%$ & $161 \%$ & $-49 \%$ \\
\hline Bahamas & $100.00 \%$ & $\mathrm{n} / \mathrm{a}$ & $36.36 \%$ & $\mathrm{n} / \mathrm{a}$ & $\mathrm{n} / \mathrm{a}$ \\
\hline Belarus & $\mathrm{n} / \mathrm{a}$ & $\mathrm{n} / \mathrm{a}$ & $\mathrm{n} / \mathrm{a}$ & $\mathrm{n} / \mathrm{a}$ & $\mathrm{n} / \mathrm{a}$ \\
\hline China & $100.00 \%$ & $41.67 \%$ & $72.22 \%$ & $-58 \%$ & $73 \%$ \\
\hline Hong Kong & $0.00 \%$ & $75.00 \%$ & $57.14 \%$ & $\mathrm{n} / \mathrm{a}$ & $-24 \%$ \\
\hline Israel & $46.94 \%$ & $34.10 \%$ & $33.48 \%$ & $-27 \%$ & $-2 \%$ \\
\hline India & $71.43 \%$ & $87.50 \%$ & $82.35 \%$ & $23 \%$ & $-6 \%$ \\
\hline Cayman Island & $\mathrm{n} / \mathrm{a}$ & $\mathrm{n} / \mathrm{a}$ & $\mathrm{n} / \mathrm{a}$ & $\mathrm{n} / \mathrm{a}$ & $\mathrm{n} / \mathrm{a}$ \\
\hline Latvia & $\mathrm{n} / \mathrm{a}$ & $\mathrm{n} / \mathrm{a}$ & $50.00 \%$ & $\mathrm{n} / \mathrm{a}$ & $\mathrm{n} / \mathrm{a}$ \\
\hline Liechtenstein & $0.00 \%$ & $100.00 \%$ & $50.00 \%$ & $\mathrm{n} / \mathrm{a}$ & $-50 \%$ \\
\hline Morocco & $\mathrm{n} / \mathrm{a}$ & $100.00 \%$ & $100.00 \%$ & $\mathrm{n} / \mathrm{a}$ & $0 \%$ \\
\hline Monaco & $100.00 \%$ & $90.91 \%$ & $100.00 \%$ & $-9 \%$ & $10 \%$ \\
\hline Malaysia & $100.00 \%$ & $0.00 \%$ & $\mathrm{n} / \mathrm{a}$ & $-100 \%$ & $\mathrm{n} / \mathrm{a}$ \\
\hline Romania & $\mathrm{n} / \mathrm{a}$ & $\mathrm{n} / \mathrm{a}$ & $0.00 \%$ & $\mathrm{n} / \mathrm{a}$ & $\mathrm{n} / \mathrm{a}$ \\
\hline Russian Fed. & $14.29 \%$ & $52.17 \%$ & $55.56 \%$ & $265 \%$ & $6 \%$ \\
\hline Saudi Arabia & $\mathrm{n} / \mathrm{a}$ & $\mathrm{n} / \mathrm{a}$ & $33.33 \%$ & $\mathrm{n} / \mathrm{a}$ & $\mathrm{n} / \mathrm{a}$ \\
\hline Slovenia & $\mathrm{n} / \mathrm{a}$ & $22.22 \%$ & $0.00 \%$ & $\mathrm{n} / \mathrm{a}$ & $-100 \%$ \\
\hline Singapore & $100.00 \%$ & $91.67 \%$ & $88.89 \%$ & $-8 \%$ & $-3 \%$ \\
\hline Chinese Taipei & $100.00 \%$ & $60.00 \%$ & $73.91 \%$ & $-40 \%$ & $23 \%$ \\
\hline Ukraine & $\mathrm{n} / \mathrm{a}$ & $0.00 \%$ & $50.00 \%$ & $\mathrm{n} / \mathrm{a}$ & $\mathrm{n} / \mathrm{a}$ \\
\hline Uzbekistan & $\mathrm{n} / \mathrm{a}$ & $\mathrm{n} / \mathrm{a}$ & $\mathrm{n} / \mathrm{a}$ & $\mathrm{n} / \mathrm{a}$ & $\mathrm{n} / \mathrm{a}$ \\
\hline Virgin Islands & $\mathrm{n} / \mathrm{a}$ & $\mathrm{n} / \mathrm{a}$ & $\mathrm{n} / \mathrm{a}$ & $\mathrm{n} / \mathrm{a}$ & $\mathrm{n} / \mathrm{a}$ \\
\hline South Africa & $100.00 \%$ & $10.00 \%$ & $57.14 \%$ & $-90 \%$ & $471 \%$ \\
\hline Non-OECD & $56.99 \%$ & $44.41 \%$ & $45.61 \%$ & $-22 \%$ & $3 \%$ \\
\hline Total & $14.48 \%$ & $17.89 \%$ & $17.74 \%$ & $24 \%$ & $-1 \%$ \\
\hline
\end{tabular}

Note: The percentages in this table reflect the ratios of the number of co-inventions to total inventions in each country. Source: OECD Database of Triadic Patent Family. 
Table 8. Shared inventions and the number of patents, OECD countries

\begin{tabular}{|lrc|}
\hline & \multicolumn{2}{c|}{ Percent of world total } \\
\cline { 2 - 3 } Country & Patents & $\begin{array}{c}\text { Shared } \\
\text { inventions }\end{array}$ \\
\hline US & $55.8 \%$ & $31.8 \%$ \\
Japan & $10.7 \%$ & $5.5 \%$ \\
Germany & $7.5 \%$ & $10.9 \%$ \\
France & $5.7 \%$ & $6.4 \%$ \\
UK & $5.5 \%$ & $10.9 \%$ \\
Sweden & $2.5 \%$ & $3.2 \%$ \\
Switzerland & $1.9 \%$ & $5.9 \%$ \\
Italy & $1.8 \%$ & $2.4 \%$ \\
Canada & $1.7 \%$ & $3.6 \%$ \\
Netherlands & $1.1 \%$ & $2.2 \%$ \\
EU & $26.9 \%$ & $27.1 \% 1$ \\
OECD & $98.4 \%$ & $94.2 \%$ \\
\hline
\end{tabular}

Source: OECD Database of Triadic Patent Family.

$1 . \quad$ Net of intra-EU co-operation.

Table 9. Role of international co-operation in non-OECD countries

\begin{tabular}{|c|c|c|c|c|c|c|c|}
\hline \multirow[b]{2}{*}{ Country } & \multicolumn{5}{|c|}{ Number of patents (unweighted) } & \multirow[b]{2}{*}{ Wted } & \multirow[b]{2}{*}{ Ave share } \\
\hline & US & EU & US\&EU & OECD & Total & & \\
\hline Israel & 137 & 47 & 24 & 176 & 179 & 64.3 & $35.9 \%$ \\
\hline Russian Fed. & 21 & 10 & 0 & 31 & 34 & 17.2 & $50.5 \%$ \\
\hline India & 22 & 14 & 2 & 36 & 36 & 13.9 & $38.7 \%$ \\
\hline China & 25 & 4 & 1 & 33 & 33 & 10.3 & $31.1 \%$ \\
\hline South Africa & 5 & 15 & 3 & 20 & 20 & 8.8 & $44.2 \%$ \\
\hline Chinese Taipei & 24 & 7 & 0 & 31 & 31 & 8.5 & $27.4 \%$ \\
\hline Brazil & 23 & 15 & 12 & 26 & 26 & 5.0 & $19.2 \%$ \\
\hline Argentina & 9 & 3 & 0 & 12 & 12 & 4.8 & $39.8 \%$ \\
\hline Monaco & 14 & 15 & 14 & 15 & 15 & 4.6 & $30.4 \%$ \\
\hline Singapore & 8 & 13 & 2 & 22 & 22 & 3.3 & $15.2 \%$ \\
\hline Total & 288 & 143 & 58 & 402 & 408 & 140.8 & $34.5 \%$ \\
\hline
\end{tabular}

Note: The number in each cell identifies a country as a partner in the invention, not necessarily the exclusive one. The "Total" column refers to the total number of shared inventions in each country. US\&EU refers to the number of collaborations involving both the US and EU.

Source: OECD Database of Triadic Patent Family.

Table 10. Trend in shared inventions between the US and EU

\begin{tabular}{|c|c|c|c|c|c|c|c|}
\hline \multirow{2}{*}{ Technology } & \multirow{2}{*}{ Year } & \multirow{2}{*}{$\begin{array}{l}\text { Numer of } \\
\text { patents }\end{array}$} & \multicolumn{2}{|c|}{ Weighted share } & \multicolumn{3}{|c|}{ Ave share } \\
\hline & & & US & $\mathbf{E U}$ & US & EU & Both \\
\hline & $1988-1989$ & 2 & 0.96 & 0.51 & $48 \%$ & $26 \%$ & $74 \%$ \\
\hline & 1990-1992 & 13 & 5.88 & 3.71 & $45 \%$ & $29 \%$ & $74 \%$ \\
\hline Medical preparations & 1993-1995 & 5 & 0.75 & 1.42 & $15 \%$ & $28 \%$ & $43 \%$ \\
\hline Total (Med. prep) & & 20 & 7.60 & 5.64 & $38 \%$ & $28 \%$ & $66 \%$ \\
\hline \multirow[t]{2}{*}{ Prostheses etc. } & 1990-1992 & 12 & 2.71 & 0.13 & $23 \%$ & $1 \%$ & $24 \%$ \\
\hline & 1993-1995 & 10 & 6.78 & 1.69 & $68 \%$ & $17 \%$ & $85 \%$ \\
\hline Total (prostheses) & & 22 & 9.49 & 1.82 & $43 \%$ & $8 \%$ & $51 \%$ \\
\hline Surgery & 1993-1995 & 2 & 1.33 & 0.33 & $67 \%$ & $17 \%$ & $83 \%$ \\
\hline Grand total & & 44 & 18.42 & 7.79 & $42 \%$ & $18 \%$ & $60 \%$ \\
\hline
\end{tabular}

Source: OECD Database of Triadic Patent Family. 
Table 11. Trend in shared inventions between the US and Japan

\begin{tabular}{|c|c|c|c|c|c|c|c|}
\hline \multirow{2}{*}{ Technology } & \multirow{2}{*}{ Year } & \multirow{2}{*}{$\begin{array}{c}\text { Number of } \\
\text { patents }\end{array}$} & \multicolumn{2}{|c|}{ Weighted share } & \multicolumn{3}{|c|}{ Ave share } \\
\hline & & & US & Japan & US & Japan & Both \\
\hline \multirow[t]{3}{*}{ Medical preparations } & $1988-1989$ & 49 & 24.41 & 23.03 & $50 \%$ & $47 \%$ & $97 \%$ \\
\hline & 1990-1992 & 79 & 36.50 & 38.02 & $46 \%$ & $48 \%$ & $94 \%$ \\
\hline & 1993-1995 & 108 & 66.86 & 36.31 & $62 \%$ & $34 \%$ & $96 \%$ \\
\hline Total medical prep. & & 236 & 127.77 & 97.35 & $54 \%$ & $41 \%$ & $95 \%$ \\
\hline \multirow[t]{3}{*}{ Prostheses etc. } & 1988-1989 & 1 & 0.33 & 0.67 & $33 \%$ & $67 \%$ & $100 \%$ \\
\hline & 1990-1992 & 26 & 10.48 & 7.70 & $40 \%$ & $30 \%$ & $70 \%$ \\
\hline & 1993-1995 & 24 & 15.12 & 6.44 & $63 \%$ & $27 \%$ & $90 \%$ \\
\hline Total protheses etc. & & 51 & 25.94 & 14.81 & $51 \%$ & $29 \%$ & $80 \%$ \\
\hline \multirow[t]{3}{*}{ Surgery } & 1988-1989 & 4 & 2.38 & 1.62 & $60 \%$ & $40 \%$ & $100 \%$ \\
\hline & 1990-1992 & 3 & 1.93 & 1.07 & $64 \%$ & $36 \%$ & $100 \%$ \\
\hline & 1993-1995 & 9 & 3.82 & 4.85 & $42 \%$ & $54 \%$ & $96 \%$ \\
\hline Total surgery & & 16 & 8.13 & 7.53 & $51 \%$ & $47 \%$ & $98 \%$ \\
\hline \multirow[t]{3}{*}{ Media devices } & 1988-1989 & 4 & 2.13 & 0.97 & $53 \%$ & $24 \%$ & $77 \%$ \\
\hline & 1990-1992 & 4 & 2.75 & 1.25 & $69 \%$ & $31 \%$ & $100 \%$ \\
\hline & 1993-1995 & 8 & 5.12 & 2.88 & $64 \%$ & $36 \%$ & $100 \%$ \\
\hline Total media devices & & 16 & 10.00 & 5.10 & $62 \%$ & $32 \%$ & $94 \%$ \\
\hline \multirow[t]{2}{*}{ Electrotherapy etc. } & 1988-1989 & 2 & 1.08 & 0.92 & $54 \%$ & $46 \%$ & $100 \%$ \\
\hline & 1993-1995 & 4 & 2.44 & 1.56 & $61 \%$ & $39 \%$ & $100 \%$ \\
\hline Total electrotherapy & & 6 & 3.53 & 2.47 & $59 \%$ & $41 \%$ & $100 \%$ \\
\hline \multirow[t]{3}{*}{ Sterilization } & 1988-1989 & 1 & 0.75 & 0.25 & $75 \%$ & $25 \%$ & $100 \%$ \\
\hline & 1990-1992 & 1 & 0.67 & 0.33 & $67 \%$ & $33 \%$ & $100 \%$ \\
\hline & 1993-1995 & 1 & 0.88 & 0.13 & $88 \%$ & $13 \%$ & $100 \%$ \\
\hline Total sterilization & & 3 & 2.29 & 0.71 & $76 \%$ & $24 \%$ & $100 \%$ \\
\hline Containers etc. & 1988-1989 & 2 & 1.20 & 0.80 & $60 \%$ & $40 \%$ & $100 \%$ \\
\hline Grand total & & 330 & 178.857559 & 128.778305 & $54 \%$ & $39 \%$ & $93 \%$ \\
\hline
\end{tabular}

Source: OECD Database of Triadic Patent Family.

Table 12. Distribution of applications by technolgy, selected countries

\begin{tabular}{|c|c|c|c|c|c|c|c|}
\hline \multirow[b]{2}{*}{ Country } & \multicolumn{5}{|c|}{ Percentage of country total (wted) } & \multicolumn{2}{|c|}{ Total (wted) } \\
\hline & $\begin{array}{c}\text { Medical } \\
\text { preparations }\end{array}$ & Surgery & Protheses etc. & Media devices & Others & Country & $\%$ grand \\
\hline US & $55.7 \%$ & $15.0 \%$ & $10.4 \%$ & $10.4 \%$ & $8.6 \%$ & 26313.85 & $27.01 \%$ \\
\hline Japan & $64.1 \%$ & $13.4 \%$ & $6.3 \%$ & $5.6 \%$ & $10.5 \%$ & 4620.33 & $4.74 \%$ \\
\hline Germany & $59.5 \%$ & $12.4 \%$ & $7.3 \%$ & $8.4 \%$ & $12.4 \%$ & 3075.02 & $3.16 \%$ \\
\hline France & $72.7 \%$ & $8.6 \%$ & $5.4 \%$ & $5.3 \%$ & $8.0 \%$ & 2467.09 & $2.53 \%$ \\
\hline UK & $65.7 \%$ & $9.2 \%$ & $7.4 \%$ & $9.3 \%$ & $8.4 \%$ & 1887.80 & $1.94 \%$ \\
\hline Sweden & $38.8 \%$ & $11.5 \%$ & $14.0 \%$ & $16.3 \%$ & $19.5 \%$ & 1218.38 & $1.25 \%$ \\
\hline Canada & $68.9 \%$ & $7.4 \%$ & $6.6 \%$ & $7.3 \%$ & $9.9 \%$ & 720.31 & $0.74 \%$ \\
\hline Switzerland & $41.6 \%$ & $15.9 \%$ & $15.4 \%$ & $11.8 \%$ & $15.3 \%$ & 675.55 & $0.69 \%$ \\
\hline Italy & $72.8 \%$ & $6.4 \%$ & $5.7 \%$ & $7.4 \%$ & $7.6 \%$ & 673.62 & $0.69 \%$ \\
\hline Netherlands & $70.9 \%$ & $8.7 \%$ & $2.6 \%$ & $6.8 \%$ & $11.0 \%$ & 551.79 & $0.57 \%$ \\
\hline$E U$ & $63.6 \%$ & $9.8 \%$ & $7.3 \%$ & $8.7 \%$ & $10.6 \%$ & 11162.71 & $11.46 \%$ \\
\hline$O E C D$ & $58.7 \%$ & $13.4 \%$ & $9.1 \%$ & $9.4 \%$ & $9.4 \%$ & 44048.63 & $45.22 \%$ \\
\hline Grand total & $59.1 \%$ & $13.0 \%$ & $8.9 \%$ & $9.3 \%$ & $9.6 \%$ & 97415.06 & $100.00 \%$ \\
\hline
\end{tabular}

Source: OECD Database of Triadic Patent Family. 
Table 13. Comparing year-of-grant drug data from the OECD and USPTO

\begin{tabular}{|c|c|c|c|c|c|c|c|}
\hline \multirow[b]{2}{*}{ Year of grant } & \multicolumn{3}{|c|}{ USPC 424 and 514} & \multicolumn{2}{|c|}{ Absolute difference } & \multicolumn{2}{|c|}{$\%$ difference } \\
\hline & 1: Triadic & 2: OECD & 3: USPTO & $1 \& 2$ & $2 \& 3$ & $1 \& 2$ & $2 \& 3$ \\
\hline 1977-79 & 155 & $\mathrm{n} / \mathrm{a}$ & 5494 & $\mathrm{n} / \mathrm{a}$ & $\mathrm{n} / \mathrm{a}$ & $\mathrm{n} / \mathrm{a}$ & $\mathrm{n} / \mathrm{a}$ \\
\hline 1980 & 537 & 1987 & 1997 & $-1,450$ & 10 & $-73 \%$ & $1 \%$ \\
\hline 1981 & 867 & 2004 & 2017 & $-1,137$ & 13 & $-57 \%$ & $1 \%$ \\
\hline 1982 & 915 & 1857 & 1862 & -942 & 5 & $-51 \%$ & $0 \%$ \\
\hline 1983 & 931 & 1669 & 1675 & -738 & 6 & $-44 \%$ & $0 \%$ \\
\hline 1984 & 1206 & 2114 & 2120 & -908 & 6 & $-43 \%$ & $0 \%$ \\
\hline 1985 & 1497 & 2156 & 2162 & -659 & 6 & $-31 \%$ & $0 \%$ \\
\hline 1986 & 1532 & 2146 & 2166 & -614 & 20 & $-29 \%$ & $1 \%$ \\
\hline 1987 & 2130 & 2518 & 2532 & -388 & 14 & $-15 \%$ & $1 \%$ \\
\hline 1988 & 2183 & 2542 & 2549 & -359 & 7 & $-14 \%$ & $0 \%$ \\
\hline 1989 & 3333 & 3603 & 3624 & -270 & 21 & $-7 \%$ & $1 \%$ \\
\hline 1990 & 3138 & 3360 & 3376 & -222 & 16 & $-7 \%$ & $0 \%$ \\
\hline 1991 & 3387 & 3662 & 3684 & -275 & 22 & $-8 \%$ & $1 \%$ \\
\hline 1992 & 3559 & 3583 & 3604 & -24 & 21 & $-1 \%$ & $1 \%$ \\
\hline 1993 & 3627 & 3855 & 3866 & -228 & 11 & $-6 \%$ & $0 \%$ \\
\hline 1994 & 3267 & 3382 & 3401 & -115 & 19 & $-3 \%$ & $1 \%$ \\
\hline 1995 & 3761 & 3877 & 3895 & -116 & 18 & $-3 \%$ & $0 \%$ \\
\hline 1996 & 4250 & 4540 & 4555 & -290 & 15 & $-6 \%$ & $0 \%$ \\
\hline 1997 & 5069 & 6115 & 6138 & $-1,046$ & 23 & $-17 \%$ & $0 \%$ \\
\hline 1998 & 4646 & 6756 & 6810 & $-2,110$ & 54 & $-31 \%$ & $1 \%$ \\
\hline 1999 & 3241 & 7145 & 7186 & $-3,904$ & 41 & $-55 \%$ & $1 \%$ \\
\hline 2000 & 1986 & 6714 & 6751 & $-4,728$ & 37 & $-70 \%$ & $1 \%$ \\
\hline
\end{tabular}

Note: Year of grant (instead of first filing date) is available from the USPTO Web site and hence employed for consistency across data sources. "Triadic" refers to patents from the Triadic Patent Families dataset. "OECD" refers to data available from the OECD. "USPTO" refers to data downloaded from the USPTO Web site: http://www.uspto.gov/web/offices/ac/ido/oeip/taf/cbcby.pdf. When calculating differences, we always use the OECD as our point of reference.

Source: OECD Database of Triadic Patent Family and USPTO Web site:

http://www.uspto.gov/web/offices/ac/ido/oeip/taf/cbcby.pdf

Table 14. Patent grant date and FDA approval for selected drugs

\begin{tabular}{|c|c|c|c|c|c|}
\hline Brand name & Company & $\begin{array}{c}\text { Patent } \\
\text { number }\end{array}$ & Patent filed & Patent grant & $\begin{array}{c}\text { FDA } \\
\text { approval }\end{array}$ \\
\hline Ambien & Lorex & 4382938 & $21-10-1981$ & $10-05-1983$ & $16-12-1992$ \\
\hline Dovonex & Bristol Myers Squibb & 4866048 & 28-03-1987 & $12-09-1989$ & 22-07-1996 \\
\hline \multirow[t]{3}{*}{ Epivir } & GlaxoSmithKline & 5047407 & 08-02-1989 & $10-09-1991$ & 17-11-1995 \\
\hline & & 6004968 & 20-03-1998 & 21-12-1999 & 18-11-1995 \\
\hline & & 6180639 & 20-02-1992 & $30-01-2001$ & 19-11-1995 \\
\hline \multirow[t]{2}{*}{ Hivid } & Roche & 4879277 & 11-08-1987 & 07-11-1989 & 19-06-1992 \\
\hline & & 5028595 & 21-08-1989 & 02-07-1991 & 20-06-1992 \\
\hline Lipitor & Pfizer & 4681893 & $30-05-1986$ & $21-07-1987$ & $17-12-1996$ \\
\hline Lotrel & Norvatis & 4410520 & 19-07-1982 & $18-10-1983$ & 03-03-1995 \\
\hline Maxaquin & Unimed Pharms & 4528287 & 17-09-1984 & 09-07-1985 & 21-02-1992 \\
\hline Paxil & GlaxoSmithKline & 4721723 & $23-10-1986$ & $26-01-1988$ & $25-06-1997$ \\
\hline Pravachol & Bristol Myers Squibb & 4346227 & 05-06-1981 & 24-08-1982 & $31-10-1991$ \\
\hline Proscar & Merck & 4760071 & 21-11-1985 & $26-07-1988$ & 19-06-1992 \\
\hline Relafen & GlaxoSmithKline & 4420639 & 12-11-1981 & $13-12-1983$ & $24-12-1991$ \\
\hline Sular & Whitehall Robins & 4892741 & 08-06-1988 & 09-01-1990 & 02-02-1995 \\
\hline Tilade & Aventis & 4474787 & 02-02-1982 & 02-10-1984 & $30-12-1992$ \\
\hline Toprol-XL & Astrazeneca & 4927640 & 12-09-1986 & $22-05-1990$ & $10-01-1992$ \\
\hline Voltaren & Norvatis & 4829088 & 14-04-1987 & 09-05-1989 & 28-03-1991 \\
\hline Zocor & Merck & 4444784 & $18-12-1980$ & 24-04-1984 & 23-12-1991 \\
\hline Zyrtec & Pfizer & 4525358 & 17-05-1983 & 25-06-1985 & 27-09-1996 \\
\hline
\end{tabular}

Data source: http://www.fda.gov; http://www.uspto.gov. 
Table 15. Regression results

\begin{tabular}{|c|c|c|c|c|}
\hline Model & 1 & 2 & 3 & 4 \\
\hline $\begin{array}{l}\text { Does model converge? } \\
\text { No. of observations used } \\
\text { Covariates } \\
\text { Random effect } \\
-2 \text { Res. log likelihood } \\
\end{array}$ & $\begin{array}{c}\text { Yes } \\
53 \\
\text { year } \\
\text { country } \\
45.6 \\
\end{array}$ & $\begin{array}{c}\text { Yes } \\
105 \\
\text { year, gov } \\
\text { country } \\
107.4 \\
\end{array}$ & $\begin{array}{c}\text { Yes } \\
105 \\
\text { year } \\
\text { country } \\
89.5 \\
\end{array}$ & $\begin{array}{c}\text { Yes } \\
105 \\
\text { year, gov } \\
\text { country } \\
87.2 \\
\end{array}$ \\
\hline $\begin{array}{l}\text { RD coefficient } \\
\text { Std err } \\
\text { t-statistic } \\
\text { p-value }\end{array}$ & $\begin{array}{c}-0.5498 \\
1.1893 \\
-0.46 \\
0.6471 \\
\end{array}$ & $\begin{array}{c}1.2452 \\
0.2085 \\
5.97 \\
<.0001\end{array}$ & $\begin{array}{c}0.4315 \\
0.1941 \\
2.22 \\
0.0291 \\
\end{array}$ & $\begin{array}{c}0.6585 \\
0.216 \\
3.05 \\
0.0031 \\
\end{array}$ \\
\hline
\end{tabular}

\begin{tabular}{|l|c|}
\hline Lag patent coefficient & 0.4024 \\
Std err & 0.09248 \\
t-statistic & 4.35 \\
p-value & $<.0001$ \\
\hline
\end{tabular}

\begin{tabular}{|l|cc|}
\hline Lag patent stock coeff & 0.7856 & 0.657 \\
Std err & 0.08173 & 0.09686 \\
t-statistic & 9.61 & 6.78 \\
p-value & $<.0001$ & $<.0001$ \\
\hline
\end{tabular}

\begin{tabular}{|l|cc|}
\hline Gov: overall F-value & $2.00 \%$ & $1.97 \%$ \\
\hline Coeff dummy=0 & 0.1339 & 0.1338 \\
\hline std error & 0.09945 & 0.07451 \\
t-statistic & 1.35 & 1.8 \\
p-value & 0.1821 & 0.0765 \\
\hline Coeff dummy=1 & -0.2525 & -0.1941 \\
\hline std error & 0.1465 & 0.125 \\
t-statistic & -1.72 & -1.55 \\
p-value & 0.0888 & 0.1246 \\
\hline
\end{tabular}

\begin{tabular}{|l|lll|}
\hline Other variables: $p$-values & & & \\
lag1 RD & 0.4595 & & \\
lag2 RD & 0.4906 & & \\
lag3 RD & 0.9659 & & \\
lag4 RD & 0.0605 & & \\
Year & 0.0039 & $<.0001 \quad<.0001$ & $<.0001$ \\
\hline
\end{tabular}




\section{FIGURES}

Figure 1. Distribution of health patents by technology class

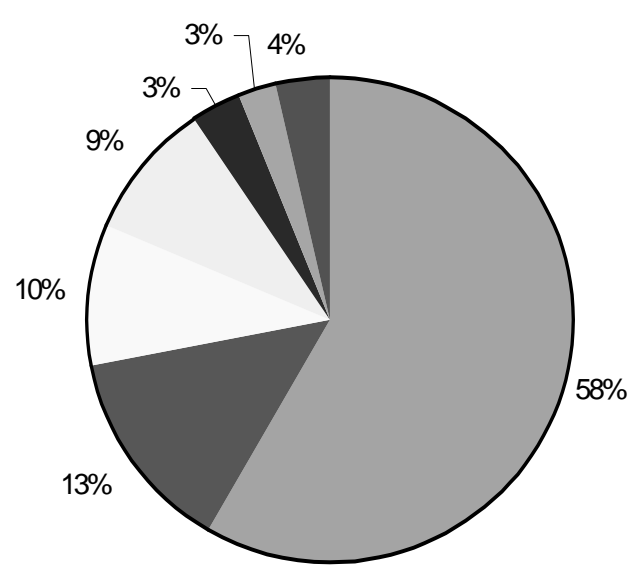

$\square$ Medical preparations

$\square$ Surgery

$\square$ Media devices

$\square$ Prostheses etc.

口Sterilization

$\square$ Electrotherapy etc.

$\square$ Others

Source: OECD Database of Triadic Patent Family.

Figure 2. Trend in health patents

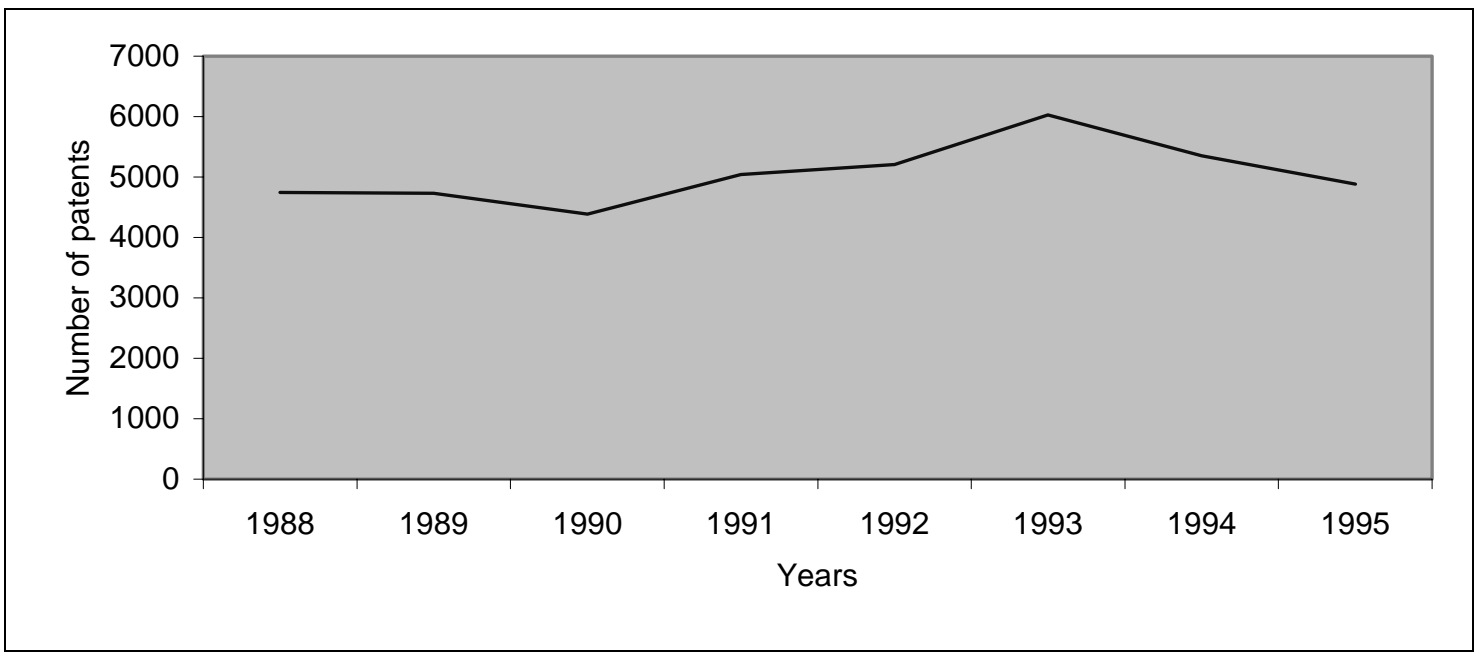

Source: OECD Database of Triadic Patent Family. 
Figure 3. Share of health patents

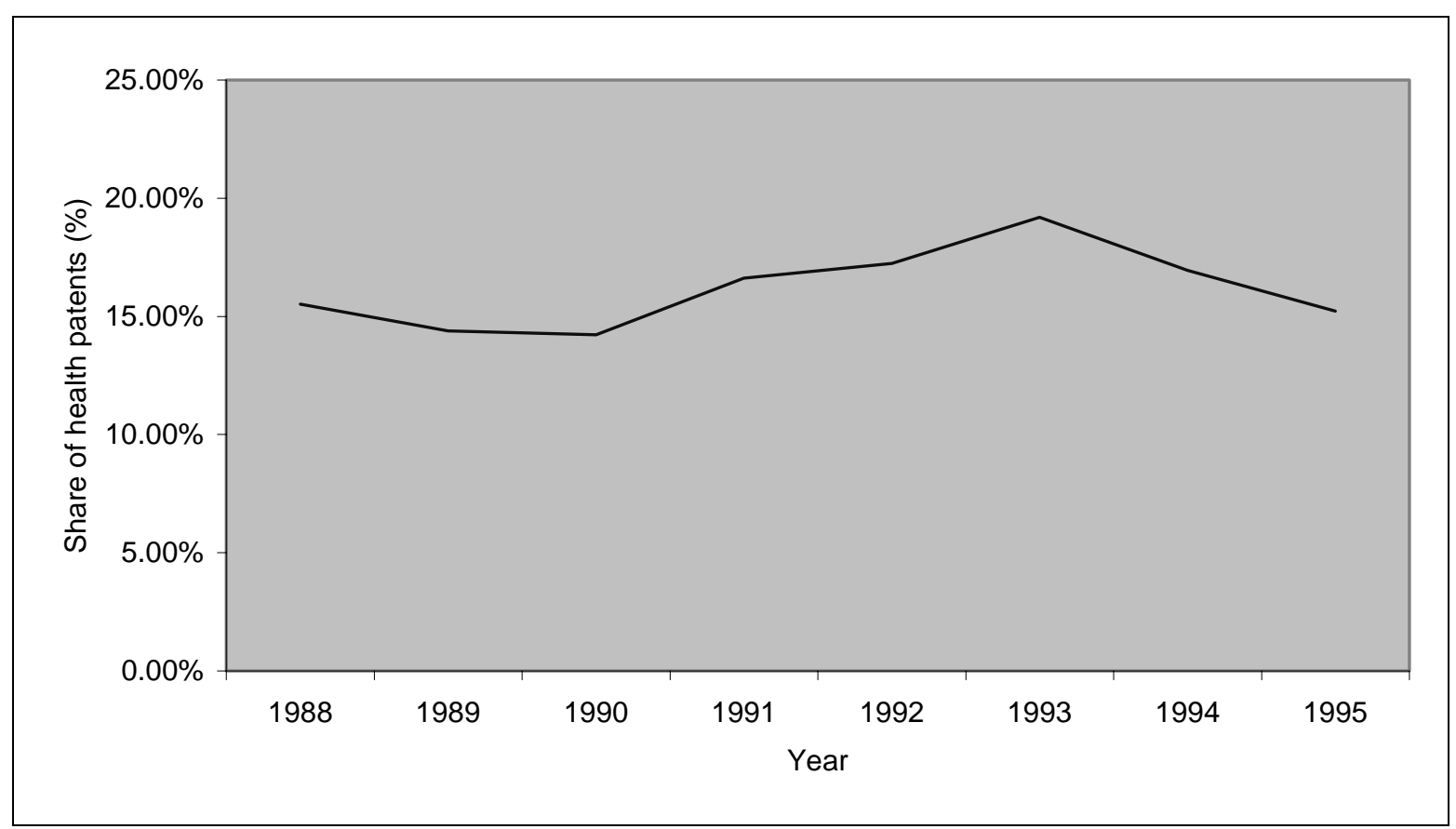

Source: OECD Database of Triadic Patent Family.

Figure 4. Evolution of selected health patent technologies

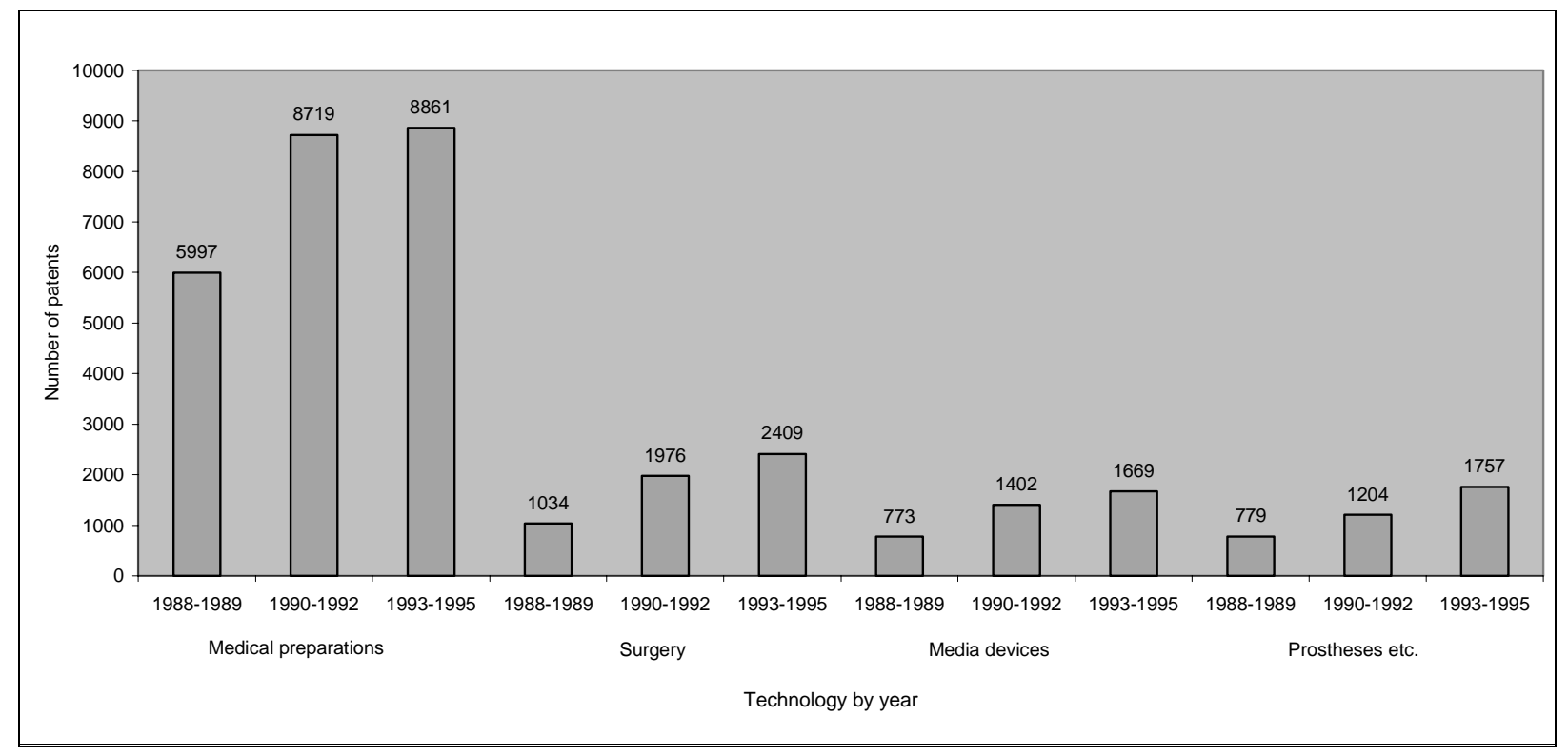

Source: OECD Database of Triadic Patent Family. 
Figure 5. Changes in absolute advantage for selected technology classes and countries

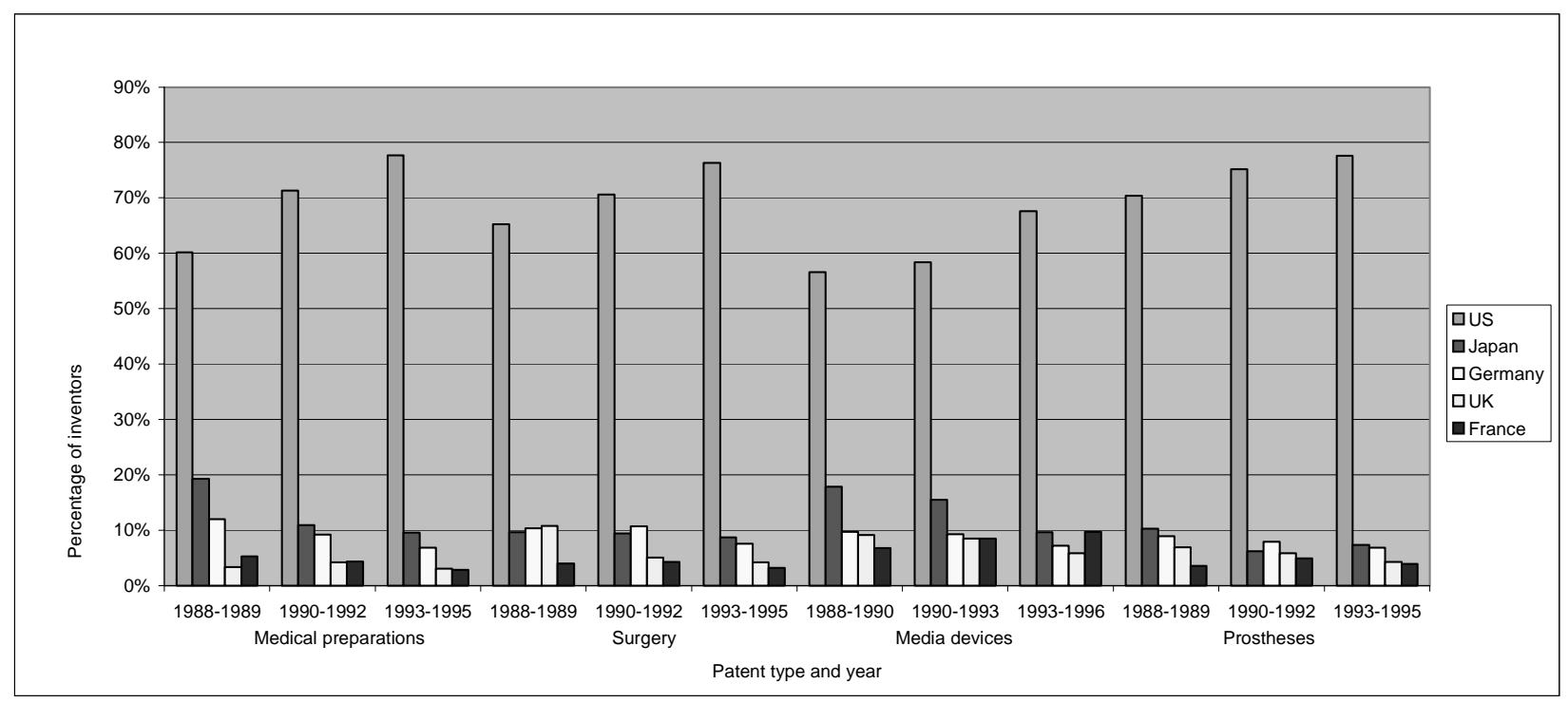

Source: OECD Database of Triadic Patent Family.

Figure 6. Evolution of shared inventions in Medical Preparations in the US

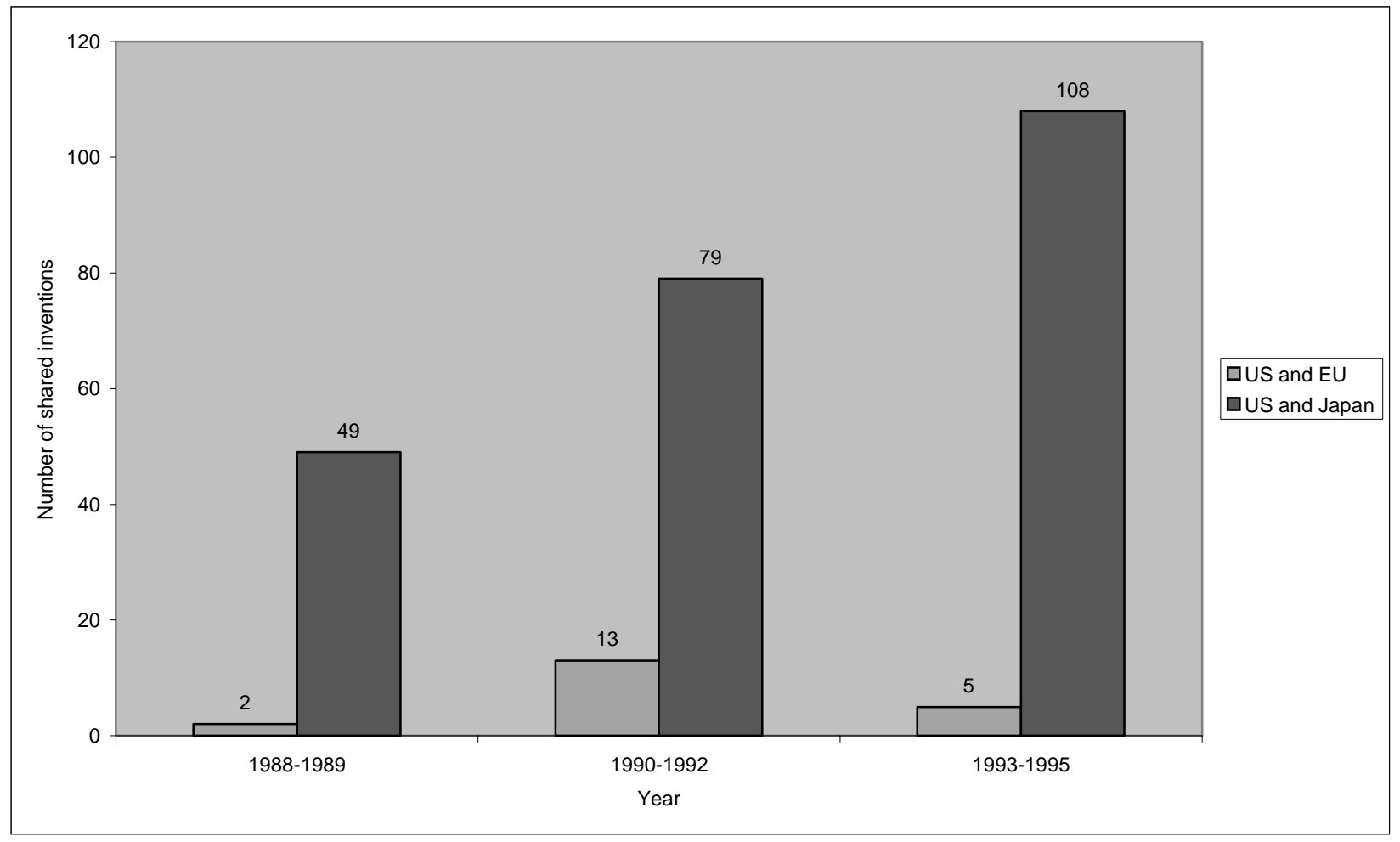

Source: OECD Database of Triadic Patent Family. 
Figure 7. Distribution of applicants across selected health technologies

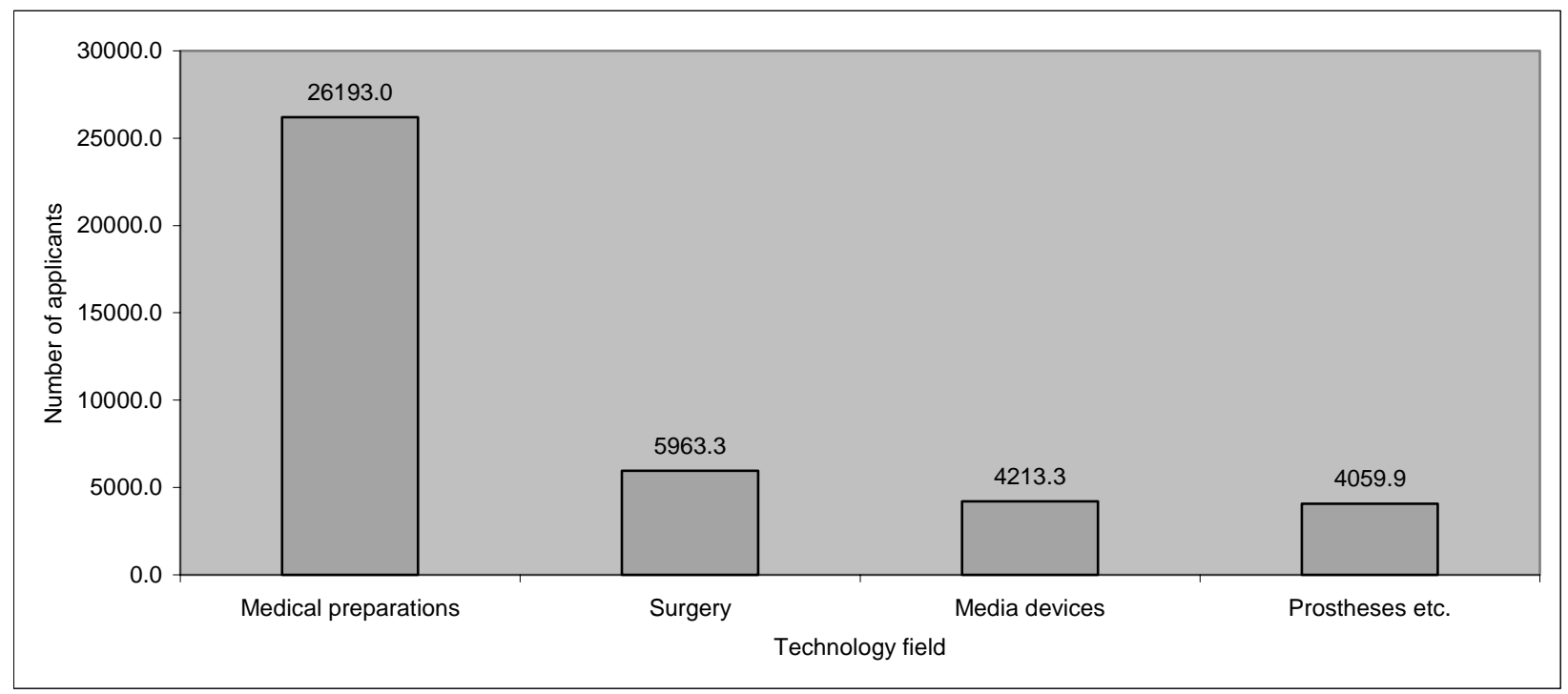

Source: OECD Database of Triadic Patent Family.

Figure 8. Evolution of applicants by selected technologies

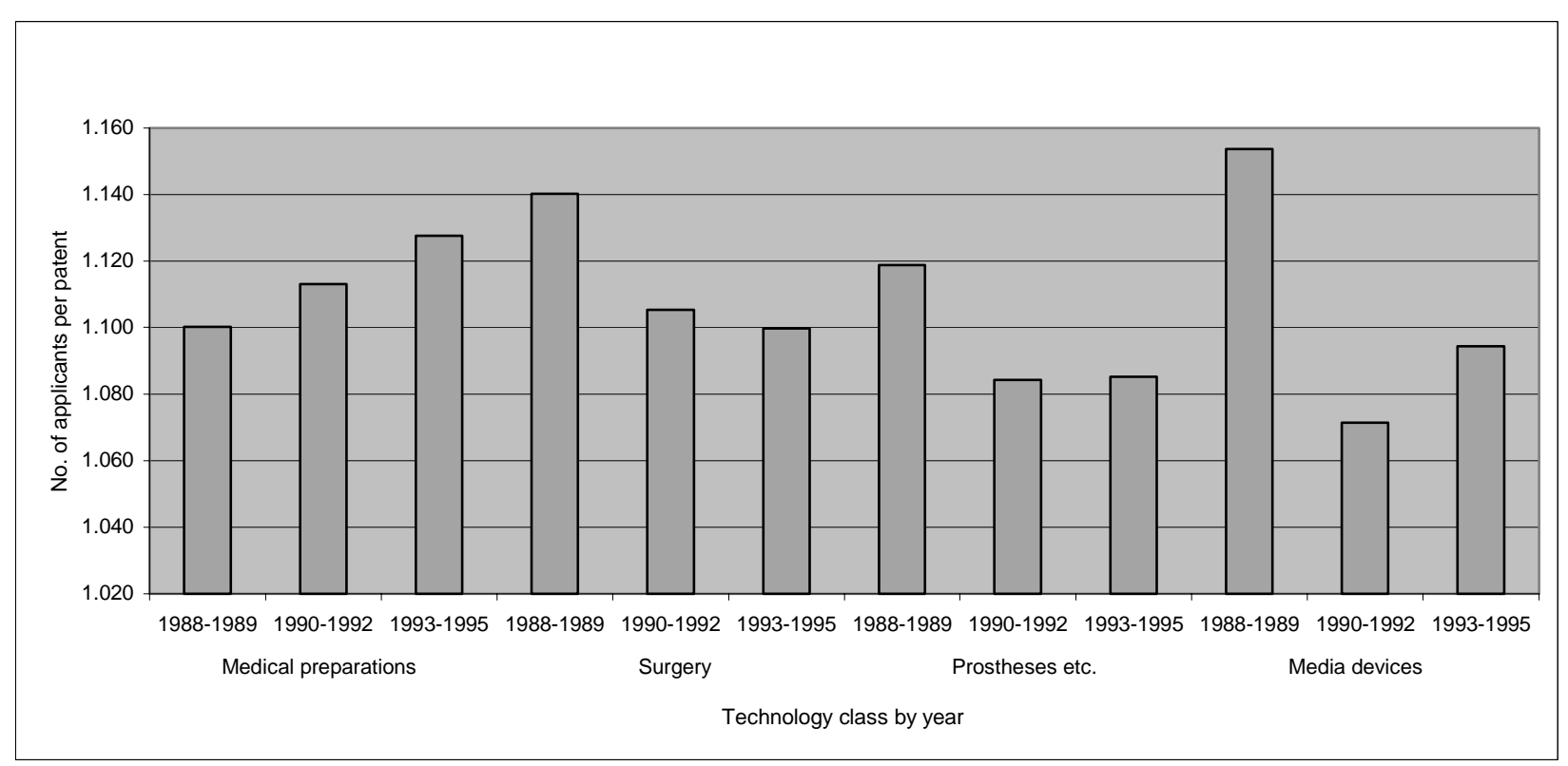

Source: OECD Database of Triadic Patent Family. 
Figure 9. Distribution across type of applicant

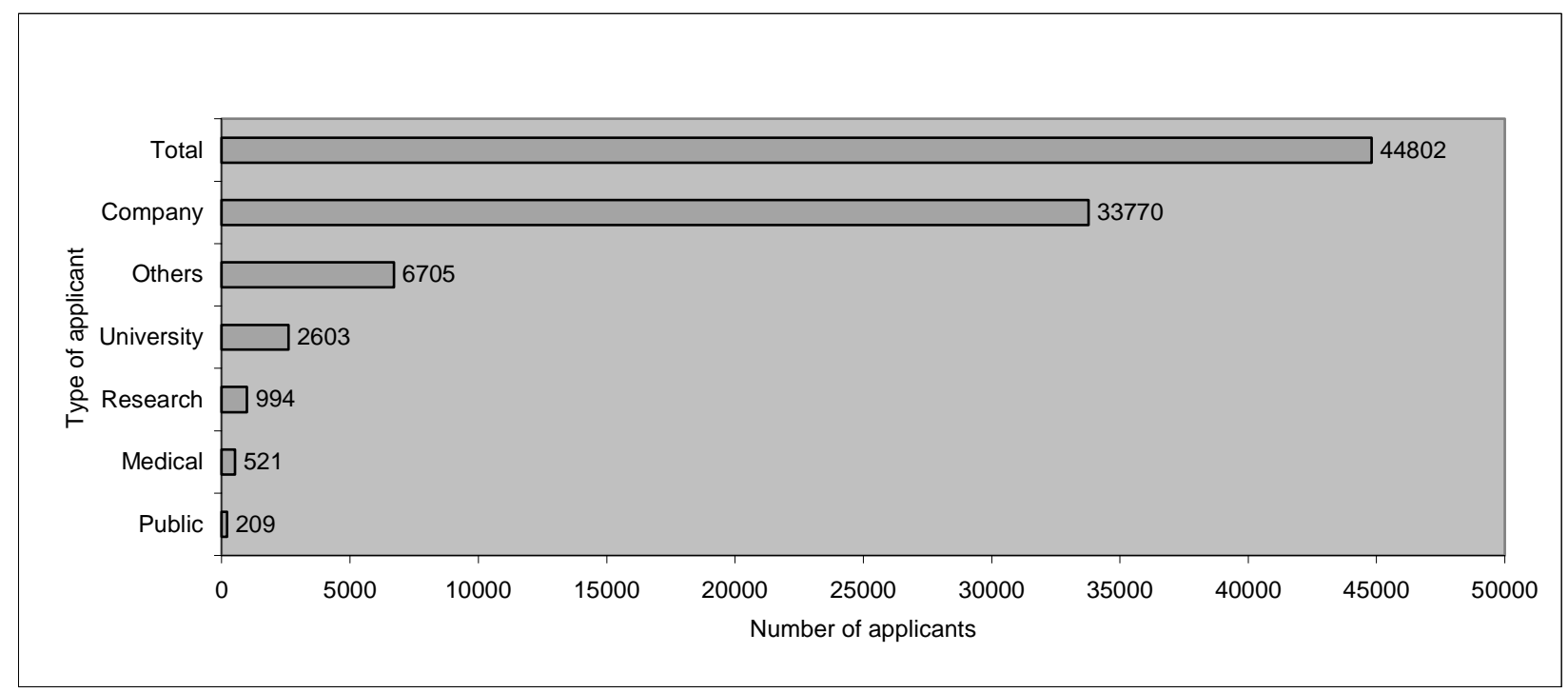

Source: OECD Database of Triadic Patent Family.

Figure 10a. Type of applicant by technology group - Medical Preparations

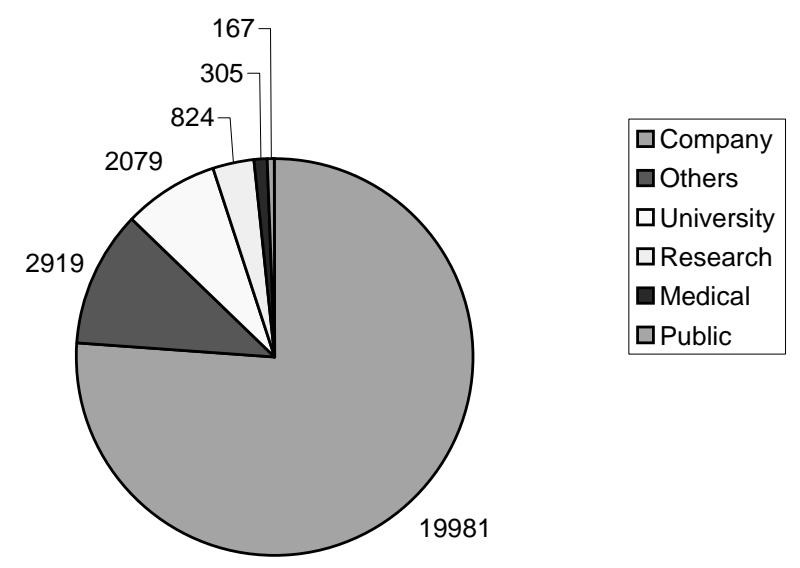

Source: OECD Database of Triadic Patent Family. 
Figure 10b. Type of applicant by technology group - Surgery

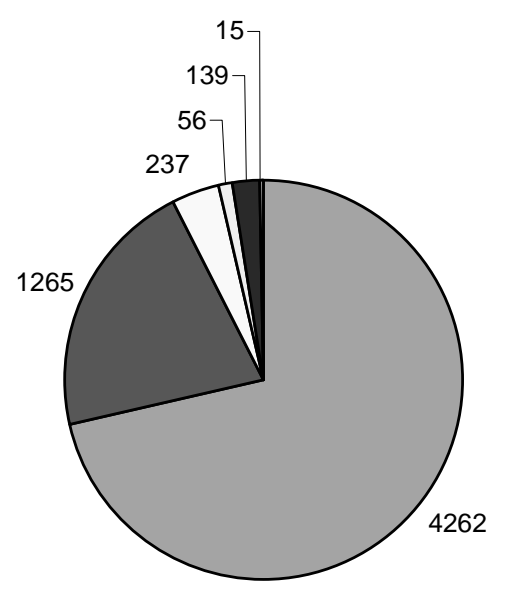

\begin{tabular}{|l|}
\hline$\square$ Company \\
$\square$ Others \\
$\square$ University \\
$\square$ Research \\
$\square$ Medical \\
$\square$ Public \\
\hline
\end{tabular}

Source: OECD Database of Triadic Patent Family.

Figure 10c. Type of applicant by technology group - Prostheses etc.

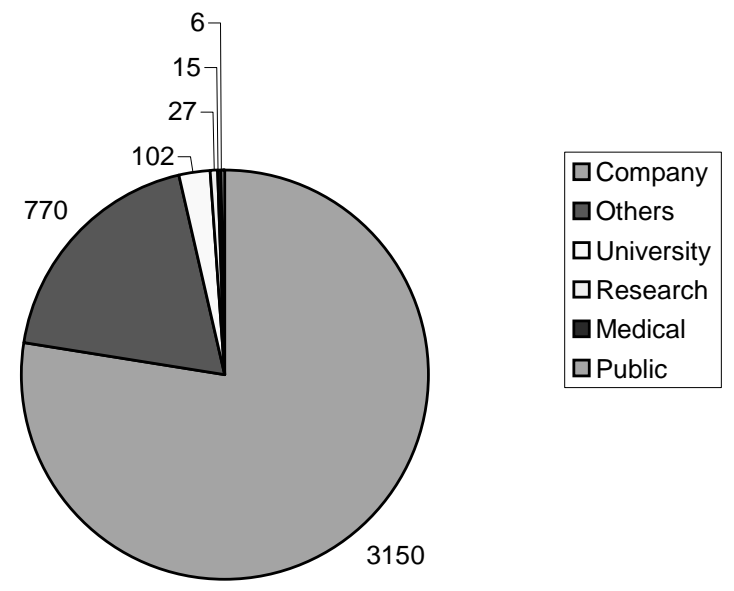

Source: OECD Database of Triadic Patent Family.

Figure 10d. Type of applicant by technology group - Media Devices etc.

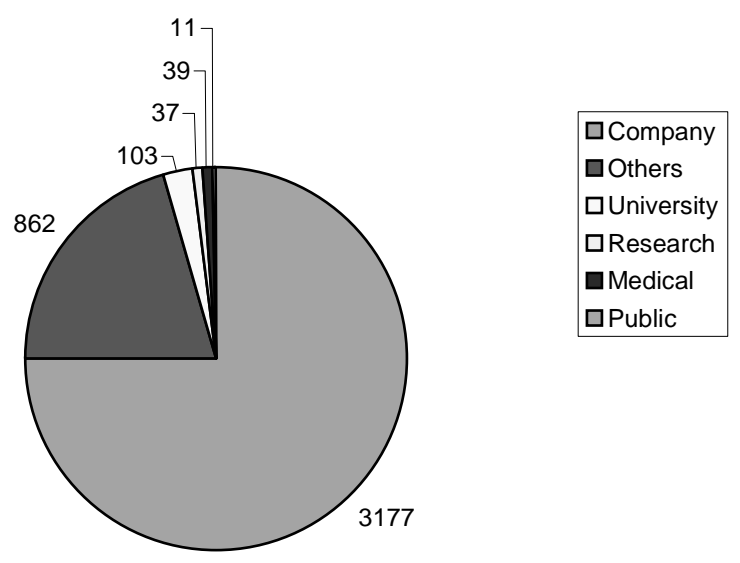

Source: OECD Database of Triadic Patent Family. 